\title{
FGF/ERK signaling pathway: how it operates in mammalian preimplantation embryos and embryo-derived stem cells
}

\author{
ANNA SOSZYŃSKA, KATARZYNA KLIMCZEWSKA and ANETA SUWIŃSKA* \\ Department of Embryology, Faculty of Biology, University of Warsaw, Warsaw, Poland
}

\begin{abstract}
The integration of extracellular signals and lineage-specific transcription factors allows cells to react flexibly to their environment, thus endowing the mammalian embryo with the capacity of regulative development. The combination of genetic and pharmacological tools allowing disruption of the fibroblast growth factor / extracellular signal-regulated kinase (FGF/ERK) pathway, together with animal models expressing lineage-specific reporters provided new insights into the role of this signaling cascade during mammalian development, as well as in embryo-derived stem cells. Here, we combine current knowledge acquired from different mammalian models to consider the universality of this cascade in specifying cellular fate across mammalian species.
\end{abstract}

KEY WORDS: FGF4, ERK, preimplantation embryo, blastocyst, epiblast, primitive endoderm

\section{Introduction}

Mammalian preimplantation embryos are characterized by a large degree of plasticity. In response to experimental manipulations, i.e., removal, addition or rearrangement of cells, they can adapt and follow normal course of development culminating in birth of the animal. Interactions between cells, typically exerted by multiple chemical factors activating numerous signaling pathways underlie the regulative nature of mammalian preimplantation embryos. Regulative development can be driven by short-range signals that trigger changes in the identity of the neighboring cells. The molecules sending and transmitting these signals have just begun to be understood. Over the last decade, fibroblast growth factor (FGF) has proved to be one of the important players, which, together with the specific transcription factor network contributes to the lineage specification process and ensures flexibility of mammalian development.

The FGF/MAPK pathway: its components and general mode of action

\section{The nature of ligands}

FGFs are a family of evolutionary conserved proteins, which are present across the phylogenetic tree from nematodes to vertebrates (Birnbaum et al., 2005). Up to date, in vertebrates, the FGF family is believed to comprise 22 proteins (Ornitz and Itoh, 2001). The molecular mass of these signaling ligands varies between 17 and $34 \mathrm{kDa}$. Based on phylogenetic analyses, the FGF members have been classified into seven sub-families, whereas from the physiological point of view, FGF proteins can be divided into three sub-groups concerning their paracrine, endocrine and intracrine mode of action. FGFs play multiple roles and are involved in multifarious biological processes, such as cell proliferation, migration, differentiation, embryo development, tissue repair and response to injury (Ornitz and Itoh, 2001; 2015). FGFs, with the exception of FGF11-14, are secreted ligands with affinity to particular receptors (FGFRs), which transmit the FGF signal via four biological cascades, involving MAPK (mitogen-activated protein kinase), PI3K/ AKT (phosphoinositide 3-kinase/protein kinase B), STAT (signal transducer and activator of transcription) or PLC $\gamma$ (phosphoinositide phospholipase C) (Ornitz and Itoh, 2015), among which the MAPKcascade, which involves ERK (extracellular signal-regulated kinase), is one of the best characterized biological pathways.

\section{The nature of receptors}

The main structural features of FGFR proteins

The FGFR family consists of four members, FGFR1 through FGFR4, which share between 55\% and 72\% homology at the protein level (Johnson and Williams, 1993). Each FGFR is a protein

\footnotetext{
Abbreviations used in this paper: EPI, epiblast; EpiSC, epiblast stem cell; ERK, extracellular signal-regulated kinase; ESC, embryonic stem cell; FGF, fibroblast growth factor; ICM, inner cell mass; MAPK, mitogen-activated protein kinase; PE, primitive endoderm; TE, trophectoderm; TSC, trophoblast stem cell; XENC, extraembryonic endoderm stem cell.
}

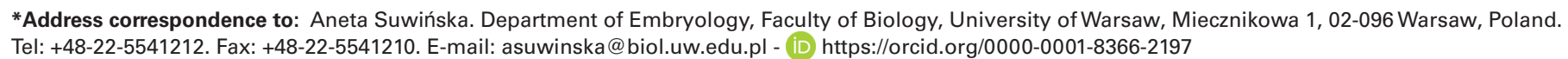




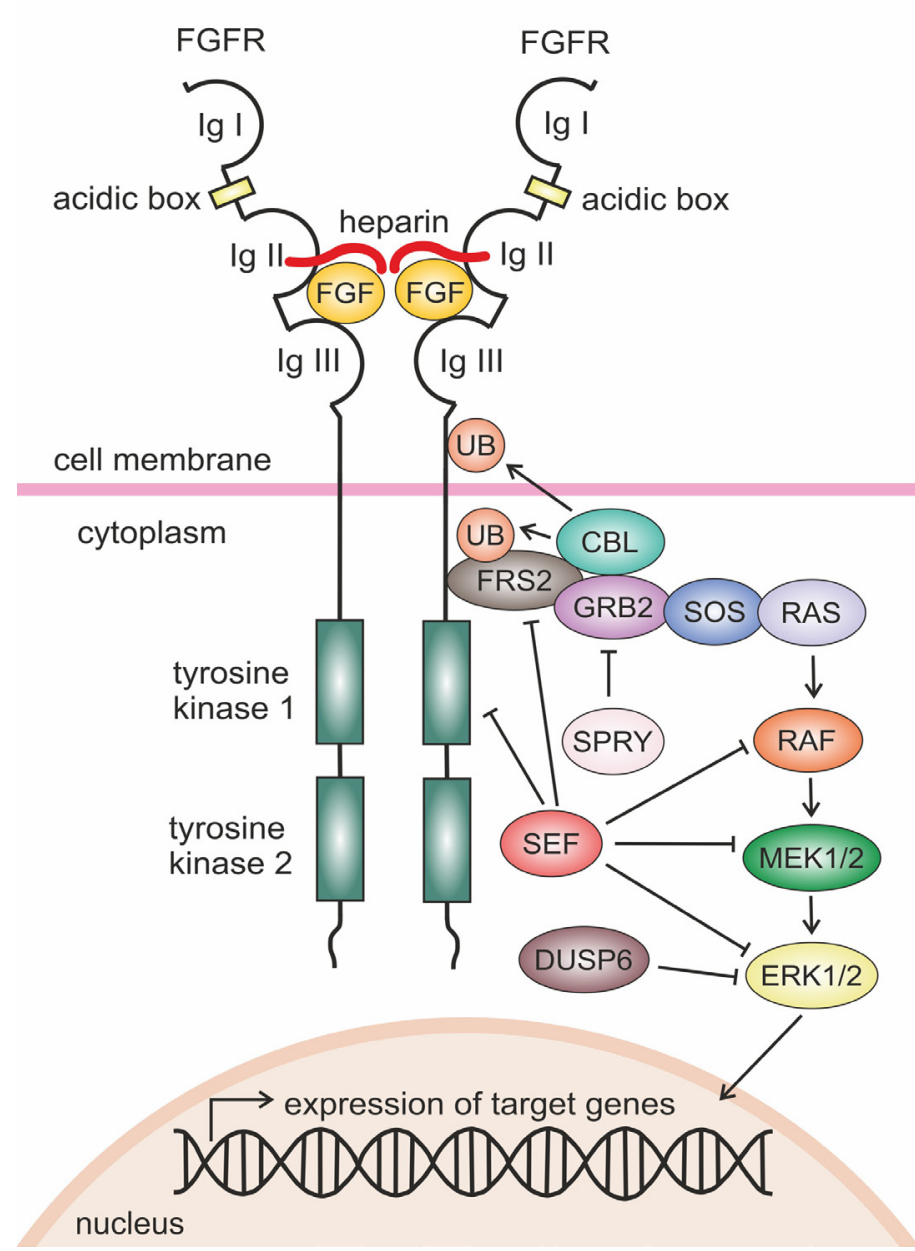

Fig. 1. Regulation of the FGF4/ERK signaling pathway. FGF signaling leads to a sequential phosphorylation of MEK and ERK, followed by its translocation to the nucleus, where it activates the downstream target genes. FGF signaling is tightly regulated at multiple levels. Heparan sulfate proteoglycans act as co-receptors and modulators of the ligand bioavailability. FGF signaling pathway is also regulated by DUSP6, SEF and SPRY proteins via negative feedback mechanisms, including dephosphorylation of the adaptor proteins, dissociation of the signaling complex and ubiquitination (UB) of the pathway components.

of $\sim 800$ amino acids with three extracellular immunoglobulinlike domains (Igl-III), a single transmembrane domain, and two intracellular tyrosine kinase domains (Fig. 1). In addition to the Ig-like domains, the extracellular region contains the acidic amino acid sequence (acidic box) located between Igl and Igll domains (reviewed by Ornitz and Itoh, 2015; Brewer et al., 2016). These extracellular domains regulate the FGF binding. Specifically, Igl and the acidic box inhibit the formation of ligand-receptor complex (Kalinina et al., 2012), while IgIl and IgIII are required for the interaction of the receptor with FGF (Plotnikov et al., 1999; 2000). The transmembrane part of the receptor allows signal transduction from extracellular ligand-binding region into the intracellular domain. This region also maintains conformation, which is necessary for the ligand-dependent activation. Finally, the intracellular domain is composed of the juxtamembrane region, followed by two tyrosine kinase domains with catalytic activity, and a carboxy-terminal tail
(Fig. 1). This domain is required for binding of proteins, in particular PKC (protein kinase C) and FRS2 (fibroblast growth factor receptor substrate 2), as well as signaling by autophosphorylation (reviewed by Bottcher and Niehrs, 2005).

\section{Mechanisms for FGFR diversity}

Fgfrgenes, through alternative splicing, can produce numerous FGFR isoforms. Among the conventional FGFRs, FGFR1, FGFR2, and FGFR3 undergo alternative splicing of exons encoding the carboxyl-terminus of the Iglll domain to generate two additional splice variants of IgIII, referred to as IIIb and IIIc (Miki et al., 1992; Werner et al., 1992; Chellaiah et al., 1994). These $b$ and $c$ isoforms have distinct ligand-binding specificities and their expression is regulated in a tissue-specific manner (Orr-Urtreger et al., 1993). Generally, FGFR b splice variants are restricted to the epithelial lineages and activated by mesenchymally expressed FGF ligands, such as members of FGF7 and FGF10 sub-families (Yan etal., 1993; Min et al., 1998). In contrast, FGFR c splice variants are specific to mesenchymal tissues and bind FGF ligands (for example FGF8) that are preferentially expressed in epithelial cells (MacArthur et al., 1995). Alternative splicing is particularly important for FGFR2 function (Yeh et al., 2003). Unlike in FGFR1-3, Iglll domain of FGFR4 is not alternatively spliced (Partanen et al., 1991).

Due to the fact that the FGFR $b$ and $c$ isoforms are important for specificity of the FGF binding, and because the IgllI domains of FGFRs share some degree of sequence similarity, one might conclude that the same Iglll splice variant would be activated by different FGF ligands. However, this is not the case. For instance, FGF7 activates only FGFR2 b, despite the fact that two additional receptors, FGFR1 and FGFR3, have also the same Iglllb splice variant (Ornitz et al., 1996). This indicates that there is the second mechanism for receptor diversity, different from the Iglll splice variant confering the FGF binding specificity (reviewed by Powers et al., 2000).

\section{The step-by-step course of FGF signal transduction}

The FGF/ERK signaling pathway is initiated upon a high affinity binding of a ligand FGF molecule to its receptor - FGFR (Lin et. al., 1997). Although the FGF-specific receptors exist as monomers in the absence of extracellular biological cues, binding of FGF results in dimerization of the two ligand-bound receptor subunits (Schlessinger et al., 2000). The FGF-dependent dimerization leads to a conformational change of the intracellular domain of FGFR, which is crucial for activation of the receptor kinase domain, and conveys the biological message triggered by FGF further on via a series of phosphorylation reactions (Sarabipour and Hristova, 2016). Receptor kinase domains of the dimerized receptor induce a stepwise trans-autophosphorylation event of tyrosine residues located within the cytoplasmic domains of both FGFR dimer partners. This process has been especially well studied in FGFR1, where seven tyrosine residues undergo a three-step phosphorylation (Lew et al., 2009). The first stage is phosphorylation of tyrosine 653 located in the activation loop of the kinase domain, which enhances the intrinsic FGFR catalytic activity up to 50-100 fold, hereby bringing the receptor to its fully active state. Next, tyrosine 583 and 585 from the kinase insert region, tyrosine 463 of the juxtamembrane region, and tyrosine 766 of the $\mathrm{C}$-terminal part are autophosphorylated. The last step of receptor trans-autophosphorylation event occurs on tyrosine 654 of the activation loop and brings about a 
further 10-fold increase in the receptor activity and finally ends up in activation of the tyrosine 730 residue (Mohammadi et al., 1996a; Foehr et al., 2001; Furdui et al., 2006; Lew et al., 2009).

The activated phospho-tyrosine residues of FGFRs function as docking sites recruiting adaptor proteins involved in the mechanism of downstream signal transduction and link FGF signaling to the MAPK pathway (Fig. 1). The first scaffold protein that acts as a substrate for an activated FGF receptor is the lipid-anchored adaptor protein FRS2 (Fig. 1) (Burgar et al., 2002). The N-terminal part of this adaptor contains a phospho-tyrosine-binding domain, vital for interaction with the cytoplasmic domain of FGFR (Yan et al., 2002), whereas the C-terminal tail contains binding sites for other scaffold proteins (Ong et al., 2000). FRS2 becomes recruited to the cytoplasmic domain of FGFR and subsequently activated by phosphorylation on multiple tyrosine residues within its phosphotyrosine-binding domain (Gotoh, 2008). Binding of FRS2 enables to recruit the adaptor protein GRB2 (growth factor receptor bound protein 2) - another crucial player linking the FGF signaling and MAPK cascade (Fig. 1) (Kouhara et al., 1997). GRB2 possesses two SRC homology 3 domains, which constitutively bind SOS (son of sevenless) protein and form together a signaling complex (Simon and Schreiber 1995; Kouhara et al., 1997). SOS is a guanine nucleotide exchange factor acting on the RAS (resistance to audiogenic seizures) sub-family of small GTPases. It is critical for embryonic development, since mouse SOS1 knockouts display a phenotype of mid-gestational embryonic lethality with impaired placental development which is associated with insufficient activity of ERK kinase in this organ (Qian et al., 2000). The whole FRS2/ GRB2/SOS complex translocates to the close proximity of the cell membrane, nearby the yet inactive RAS, which is attached to the cytoplasmic side of the cell membrane. SOS activates the RAS-bound GDP protein by catalyzing a GDP-GTP exchange (Margarit et al., 2003). RAS proteins play essential role in transmitting multifarious signals within cells and are involved in multiple biological processes, such as growth, cell migration and adhesion, cytoskeletal integrity, survival and differentiation (Rajalingam etal., 2007). In its active GTP-bound state, RAS is able to dissociate from the FRS2/GRB2/SOS complex and recruit its critical effector RAF-1 (rapidly accelerated fibrosarcoma protein 1). RAF family comprise three kinases with serine/threonine-specific activity: ARAF, B-RAF and C-RAF (also known as RAF-1). All of them were found to be activators of MAPK signaling, however A-RAF has a lower activity than the remaining two family members (Matallanas et al., 2011). The active RAF-1 phosphorylates and activates the first kinases of the MAPK cascade, called MEKs (mitogenactivated protein kinase kinase), at serine 217 and 221 residues within their activation loop (Vogel et al., 2006). MEK1 and MEK2 are dual specificity mitogen-activated protein kinases, which exert their function by phosphorylating tyrosine 204/187 and threonine 202/185 of ERK1 and ERK2 (also known as MAPK1 and MAPK2, i.e., mitogen-activated protein kinases 1 and 2) leading to their activation and further transduction of the FGF signal (Roskoski, 2012). N-terminal domain of MEKs contains a so called D-domain, responsible for binding and phosphorylation of ERK proteins ( $\mathrm{Xu}$ et al., 1999), a nuclear export sequence (NES), and an inhibitory segment. Function of the MEK C-terminal domain is elusive, but it is believed to regulate both the cytoplasmic localization of MEK and the activation of ERK (Cha et al., 2001). Research on MEK knockout mice has shown that MEK1 is fundamental for proper development, since Mek 1 - mice die at mid-gestation (E10.5), due to abnormal development and insufficient vascularization of the placenta (Bissonauth et al., 2006). In contrast, MEK2 seems to be dispensable, as the $\mathrm{Mek}^{-/-}$mice are viable, fertile and manifest a normal phenotype (Bélanger et al., 2003). Activated ERK kinases are the last element of the kinase cascade. In humans, ERK1 and ERK2 manifest $84 \%$ of identity within their amino acid sequences and exhibit many overlapping roles (Lloyd, 2006). However, experiments conducted on knockout mice have shown that these proteins are not entirely functionally redundant. Disruption of Erk1 gene does not impair normal development of the mutant mice, which are viable and display completely normal phenotype (Nekrasova et al., 2005). In contrast, Erk2 ${ }^{--}$mice die soon after implantation due to severe abnormalities in the placental development (Saba-ElLeil et al., 2003), which cannot be compensated by ERK1 protein. Therefore, ERK2 is believed to regulate the propagation of polar trophectoderm cells (Saba-El-Leil et al., 2003). Moreover, ERK1 has been reported to be unable to compensate in vivo for the loss of ERK2 in terms of mesoderm differentiation during mouse embryonic development (Yao et al., 2003). Finally, ERK kinases translocate to the nucleus, where they activate the transcription of proteins involved in biological processes, such as proliferation or differentiation, thus translating ultimately the FGF signal into a precise cellular response (Milne et al., 1994; Chung et al., 1998; Murphy et al., 2002; Morton et al., 2003).

\section{Regulation of FGF/ERK signal transduction pathway: activators and repressors}

Taking under consideration the multiple biological responses evoked by FGF signaling, this cascade needs to be tightly and precisely coordinated at many levels. The first stage of FGF/ERK pathway regulation is provided by glycosaminoglycans, such as heparin, that link together two FGF-bound FGFR subunits. This step is crucial for activation of the FGF receptor and assembling a stable and specific FGF:FGFR complex (Herr et al., 1997; Schlessinger et al., 2000). Moreover, binding of the FGFs to heparin or heparan sulfate proteoglycans protects FGFs from denaturation and proteolysis and limits their diffusion rate, which creates a local reservoir of FGF molecules critical for a spatially restricted activation of the FGF signaling cascade (Flaumenhaft et al., 1990; Powers et al., 2000).

The second level of FGF/ERK pathway regulation involves conformational changes in the FGFRs. Three domains (Igl, Igll and IgIII) of the FGFR extracellular part manifest, prior to the FGF binding, a conformationally open structure (Kalinina et al., 2012), which changes upon activation by FGF binding. Due to interaction between the Igl receptor domain and its Igll-IgIII region, as well as between the acidic box and the heparin binding site, the once activated receptor adopts an auto-inhibited closed structure, thus preventing any unwelcome additional interactions with FGF (Olsen et al., 2004, Kalinina et al., 2012).

Another auto-inhibitory mechanism is related to the FGFR kinase domain and has been examined in detail for FGFR1. Mohammadi and co-workers have shown that although the tyrosine residues in the activation loop of FGFR1 do not block access to the active site, the C-terminal end of the activation loop interferes with the FGF binding (Mohammadi et al., 1996b). Moreover, hydrogen bonds formed by the glutamic acid 565, asparagine 549, and lysine 641 residues, located in the kinase hinge region, act as a "molecular 
brake" inhibiting movements of the $\mathrm{N}$-terminal loop towards the $\mathrm{C}$ terminal side, which keeps the kinase domain in an auto-inhibited, inactive state (Chen et al., 2007).

The next important antagonist of FGF signaling is SPRY (Sprouty). In mammals, three Sprouty members, namely SPRY1-2 and SPRY4, have been shown to negatively regulate the FGFtriggered MAPK signal transduction (Sasaki et al., 2001; Hanafusa et al., 2002). Upon stimulation with FGF, SPRY undergoes phosphorylation at a conserved tyrosine 55 residue in a SRC-dependent fashion (Mason et al., 2001). This phosphorylated tyrosine residue becomes next a docking site for recruiting $\mathrm{SH} 2$ domain-containing adaptor proteins, such as GRB2, leading to a dissociation of GRB2 from the FRS2/GRB2/SOS complex and attenuation of the signaling (Kim and Bar-Sagi, 2004). Another example of a protein attenuator operating at this level is CBL (casitas B-lineage lymphoma) which is an E3 ubiquitin ligase. It has been reported to bind to phosphorylated FRS2/GRB2 complex and trigger ubiquitination and subsequent degradation of the activated FGFR and FRS2 (Wong et al., 2002).

SEF (similar expression to FGF) protein is another negative regulator of the FGF/ERK pathway (Fürthauer et al., 2002), whose tyrosine 330 residue was reported to be vital in exerting the inhibitory function (Ren et al., 2007). SEF has been shown to inhibit FGFR1 and FRS2 phosphorylation. This event triggers a subsequent decrease in phosphorylation of other members of the signal transduction pathway, namely RAF-1 at serine 338, MEK1/2 at serine 217 and serine 221, and ERK1/2 at threonine 202 and tyrosine 204, and, eventually, leads to attenuation of the whole FGF/ERK signaling cascade (Kovalenko et al., 2003).

Yet another regulatory mechanism operates downstream of the FGF signaling and is related to the dual serine/threonine and tyrosine phosphorylation activity of MAP kinases. DUSP6 (dualspecificity phosphatase 6), also known as MKP-3 (MAP kinase phosphatase-3), which becomes expressed upon FGF receptor activation, was reported to dephosphorylate and therefore attenuate the once activated ERK1 and ERK2 kinases (Ekerot et al., 2008).

Overall, since FGF activates various biological pathways, it is crucial to precisely regulate the FGF signal and translate it into a proper biological response. The regulatory mechanisms, which operate at both extracellular and intracellular levels, play an important role in fine-tuning of the FGF signal and help the cells to respond accordingly to the environmental cues.

\section{FGF signaling in mammalian embryo lineage specification}

It is now widely known that transcriptional networks and extracellular signals together govern the cell fate decisions during preimplantation mammalian development. This complex molecular device senses and integrates the intrinsic properties of embryonic cells, such as adhesion or polarity, as well as external cues, such as the identity of neighboring cells, and transmits this information to the nuclei of individual cells.

During preimplantation development of mammals, two differentiation events take place before the implantation of the blastocyst in the maternal uterus. The first one results in the specification of the trophectoderm (TE), which is the precursor lineage for the fetal part of the placenta, and the internally positioned inner cell mass (ICM). This cell fate decision is regulated by differential CDX2 (caudal related homeobox 2 gene) expression, resulting from a combination of cues generated by cell adhesion and activity of the Hippo signaling pathway (Nishioka et al., 2009; reviewed by Saini and Yamanaka, 2018). The second differentiation event relies on the segregation of the ICM cells into two lineages: the pluripotent epiblast (EPI) and the primitive endoderm (PE, also called hypoblast in non-rodent animals). EPI cells contribute to the embryo proper and extraembryonic tissues, i.e., the amnion, chorion and mesoderm of the yolk sac, whereas PE cells give rise to the endoderm of the yolk sac (reviewed by Chazaud and Yamanaka, 2016).

\section{The second cell fate decision: the relationship between transcriptional networks and FGF signaling pathway}

It has been reported that FGF/ERK signaling pathway is of particular importance in epiblast lineage separation from the extraembryonic PE. In mice, GATA6 (GATA binding protein 6) and NANOG (Nanog homeobox) are the earliest markers required for the specification of the PE and EPI, respectively (Chazaud et al., 2006; Kurimoto et al., 2006) (Fig. 2). Both transcription factors are present in all cells of the embryo from the 8-cell to the early blastocyst stage (32-64 cells) (Plusa et al., 2008; Guo et al., 2010). At the mid blastocyst stage (64-100 cells), the expression pattern of EPI and PE markers becomes mutually exclusive, forming an apparently random salt-and-pepper pattern (Fig. 2). Some of the ICM cells maintain GATA6 expression and downregulate NANOG which leads to specification of the PE lineage. In the remaining cells GATA6 expression is reduced, whereas NANOG expression is retained, triggering the EPI-specific genetic program (Chazaud et al., 2006; Plusa et al., 2008; Guo et al., 2010; Bessonnard et al., 2014) (Fig. 2). Even though cells at this stage are biased towards either an EPI or PE fate, they are not fully committed to their respective identities. Even at the late blastocyst stage (approx. 120 cells) PE and EPI cells can switch between alternative fates, which has been shown both in a chimera assay (Grabarek et al., 2012) and in isolated ICMs (Wigger et al., 2017). However, in undisturbed embryos this switch is observed only occasionally and refers exclusively to the conversion from PE to EPI (Plusa et al., 2008; Xenopoulos et al., 2015). Moreover, it has been shown that as late as in 90-120-cell blastocyst some inner cells co-express both GATA6 and NANOG (Saiz et al., 2016). It is speculated that only such double positive cells may choose between alternative fates. Thus, the specification process occurs asynchronously among ICM cells to ensure the balanced generation of both types of precursors (Saiz et al., 2016), however, the formation of EPI progenitors precedes that of PE progenitors (Grabarek et al., 2012; Xenopoulos et al., 2015; Bessonnard et al., 2017).

Later on, just before implantation, cells expressing GATA6 and NANOG are sorted into adjacent layers. As a consequence, in the late blastocyst the PE cells form an epithelium on the surface of the ICM, separating the EPI cells from the blastocyst cavity (Gerbe et al., 2008; Plusa et al., 2008; Meilhac et al., 2009; Frankenberg et al., 2011; Saiz et al., 2013) (Fig. 2).

It has been shown that the deletion of Gata6 results in the absence of the later PE markers, such as SOX17 (sex determining region Y-box 17), GATA4 (GATA binding protein 4) and PDGFR $\alpha$ (platelet-derived growth factor receptor $\alpha$ ) (Bessonnard et al., 2014; Schrode et al., 2014). Surprisingly, Nanog-/ mutants also lack late PE markers (Silva et al., 2009). Nanog ${ }^{-/}$knockout embryos exhibit GATA6 expression, but it is unable to induce its downstream PE 
targets. It was later suggested that NANOGexpressing cells act on their neighboring cells in a non-cell-autonomous manner, through FGF4 secretion, to induce the expression of SOX17, GATA4 and PDGFR $\alpha$ and, as a consequence, to adopt the PE fate (Messerschmidt and Kemler, 2010; Frankenberg et al., 2011). Using blastocyst complementation approach, i.e., injection of wild-type ESCs (embryonic stem cells) into E3.5 Nanog ${ }^{-/}$blastocysts, it has been shown that ESC-derived EPI is able to rescue $P E$ formation and to prevent lethality of the resulting E7.5 embryo (Messerschmidt and Kemler, 2010). These observations confirmed that apart from the GATA6, which promotes the PE fate in a cell-autonomous manner, the FGF signaling pathway acts to specify the PE in a non-cell-autonomous way.

The significance of FGF signaling in the early mouse embryo has been additionally corroborated by modulating concentration or activity of its components. The activation of the FGF4/ERK pathway by addition of exogenous FGF4 results in differentiation of all ICM cells toward the PE lineage (Yamanaka et al., 2010). Conversely, inhibition of this pathway by embryo culture in the presence of specific inhibitors initiates NANOG expression, and, as a consequence, converts all ICM cells to the EPI (Nichols etal., 2009b; Yamanaka et al., 2010). Importantly, responsiveness of ICM cells to modulation of the FGF pathway activity is progressively lost over time, but the timing of this loss differs depending on the modulation type. Between E2.75 to E3.25 ICM cells are sensitive to the stimulation with exogenous FGF (Yamanaka et al., 2010; Bessonnard etal., 2017). At this time they are insensitive to the inhibition of the FGF signaling, which is the highest between E3.25 and E3.75, i.e., at the time of establishment of the NANOG/GATA6 salt-and-pepper pattern (Bessonnard et al., 2017). However, single-cell resolution image analysis revealed that the highest ability of individual ICM cells to respond to the FGF cascade stimulation or inhibition occurs between E3.25 to E3.5 and corresponds to the period when double-positive cells, expressing both GATA6 and NANOG represent $\sim 50-75 \%$ of the ICM (Saiz et al., 2016). Single ICM cells become insensitive to the modulation of the FGF cascade activity after E4.0, when the amount of double positive cells is less than $5 \%$. These data suggest that only the fate of bipotential ICM cells can be changed in response to the alternation of the FGF pathway activity, whereas committed PE and EPI cells are insensitive to this signal (Saiz et al., 2016).

\begin{tabular}{|ccc|}
\hline $\begin{array}{c}\sim 32-64 \text { cells } \\
(\sim \mathrm{E} 3.0-\mathrm{E} 3.25)\end{array}$ & $\begin{array}{c}\sim 64-100 \text { cells } \\
(\sim \mathrm{E} 3.5-\mathrm{E} 3.75)\end{array}$ & $\begin{array}{c}>100 \text { cells } \\
(\sim \mathrm{E} 4.5)\end{array}$ \\
\hline early blastocyst & mid blastocyst & late blastocyst \\
\hline GATA6 & & \\
\hline PDGFRa & & \\
\hline & SOX17 & \\
\hline & GATA4 & SOX7 \\
\hline
\end{tabular}

co-expression of lineage-specific markers NANOG/GATA6
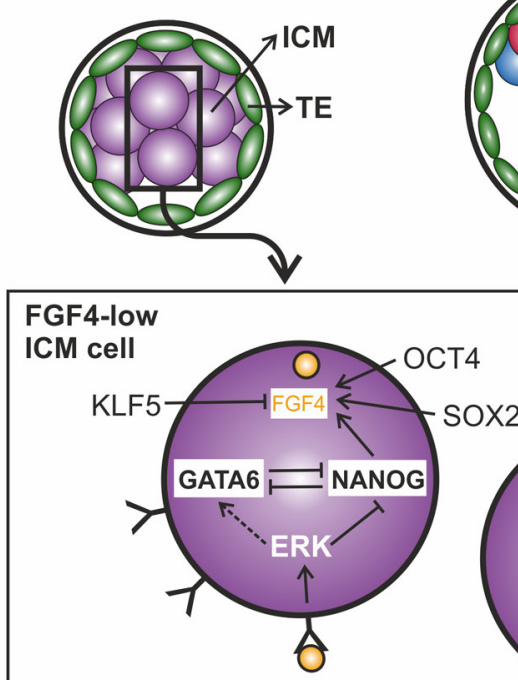

FGF4-high ICM cell

\section{Y FGFR1}

Fig. 2. The role of FGF4/ERK signaling in mouse embryogenesis. Temporal control of FGF4/ERK cascade is required for EPI/PE specification within the ICM. At E3.0-E3.25 (nascent blastocysts), ICM cells are bipotential and express both EPI (NANOG) and PE (GATA6) markers as well as FGFR1. FGF4 signals through FGFR1 to constrain NANOG and promote GATA6 expression. At E3.5 a subset of cells initiates expression of FGFR2. In these cells FGF4, acting through FGFR1 and FGFR2, maintains GATA6 expression and downregulates NANOG (i.e., activates the PE specification program). Next, it induces expression of several late PE markers, such as SOX17, PDGFR $\alpha$, GATA4, SOX7. salt and pepper distribution

lineage-biased precursors

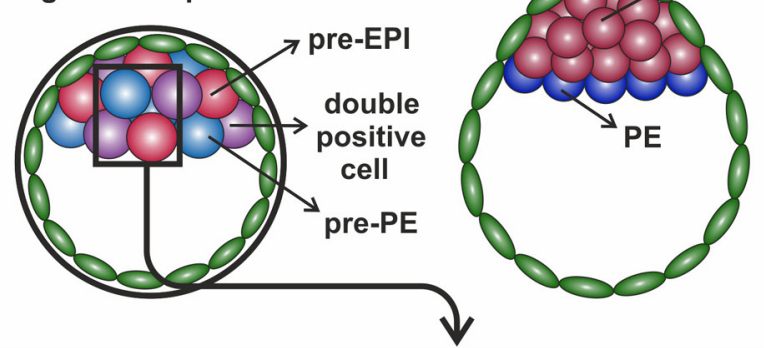

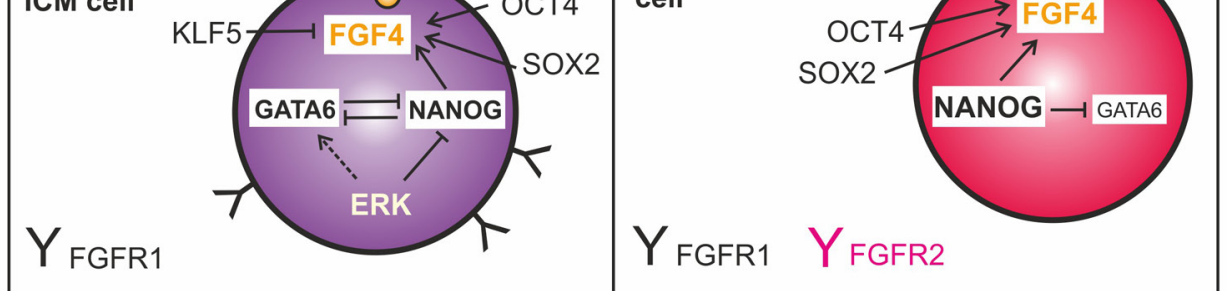


first protein that exhibits a bimodal expression within the ICM cells of the E3.25 blastocyst (32-50 cells), preceding the segregation of EPI and PE precursor cells at E3.5 (Krupa et al., 2014; Ohnishi et al., 2014). The question whether this heterogenous expression of FGF4 is a result of intrinsic stochastic fluctuations in its expression levels or the origin of ICM cells (from the first or second round of the asymmetric divisions giving rise to the embryonic inner cells) remains controversial (Morris et al., 2010; Yamanaka et al., 2010; Morris et al., 2013; Krupa et al., 2014; Mistri et al., 2018). Since the inner cells contributing to the ICM are generated in different time points, it has been proposed that those internalized in the first round (at the 8- to 16-cell transition) and expressing FGF4 at a higher level are biased to form the EPI, whereas those arising during the second round (16- to 32-cell transition) and expressing more FGFR2, are biased towards the PE fate (Morris et al., 2010; Morris et al., 2013; Krupa et al., 2014). This heterogeneity in FGF4/ FGFR2 expression has been shown to result from fluctuating levels of SOX2 (sex determining region Y-box 2) expression in the arising inner cells (Mistri et al., 2018). Chimera experiments have revealed that accumulation of the inner cells, produced in the first round of asymmetric divisions, elevates the FGF4 secretion above a certain threshold, which is sufficient to trigger activation of the FGF/ERK signaling in the remaining ICM cells and drive them towards the PE differentiation (Krupa et al., 2014).

Mutations in the components of the FGF4/ERK pathway, such as FGF4, both receptors FGFR1 and FGFR2, as well as GRB2, FRS2, and ERK2, result in peri- or postimplantation lethality (Feldman et al., 1995; Arman et al., 1998; Cheng et al., 1998; Hadari et al., 2001; Hatano et al., 2003; Saba-El-Leil et al., 2003; Chazaud et al., 2006; Kang et al., 2013; Krawchuk et al., 2013; Kang et al., 2017; Molotkov et al., 2017). The fact that such mutants survive until periimplantation period questioned the requirement for FGF4 signaling in the earlier developmental stages. The detailed analysis of $\mathrm{Fgf4}^{-/}$mutants showed that FGF4 is not necessary for initial expression of GATA6 between 8- and 32-cell stage (Kang et al., 2013; Krawchuk et al., 2013) and establishment of NANOG/GATA6 double positive ICM cells. Moreover, it was observed that treatment of Gata6 $^{--}$embryos with exogenous FGF4 does not rescue their inability to activate the PE program (Bessonnard et al., 2014; Schrode et al., 2014). These data suggest that another mechanism is responsible for the initial induction of GATA6 expression while FGF4/ERK signaling is required for its maintenance and restriction to the future PE cells after 32-cell stage (Feldman et al., 1995; Kang et al., 2013; Krawchuk et al., 2013; Ohnishi et al., 2014). Other PE-specific markers, such as PDGFR $\alpha$ and SOX17, are severely downregulated in $\mathrm{Fgf4}^{-/}$blastocysts, demonstrating the importance of the FGF4 for the establishment of a salt-and-pepper distribution of EPI and PE cells within the ICM and progression of the PE program (Kang et al., 2013). In the absence of FGF4, the PE-specific genetic program cannot proceed and, as a consequence, the late PE markers - GATA4 and SOX7 (sex determining region Y-box 7), are not expressed in the blastocysts (Kang et al., 2013).

It has been demonstrated that FGF4 expression is directly regulated by two pluripotency-associated transcription factors, SOX2 and OCT4 (octamer-binding transcription factor 4) (Yuan et al., 1995; Nichols et al., 1998; Le Bin et al., 2014) (Fig. 2). In EPI cells OCT4 and SOX2 induce FGF4 expression that promotes the PE cell fate in a non-cell-autonomous manner (Wicklow et al., 2014; Le Bin et al., 2014). Ablation of one of these transcription factors leads to a decrease in FGF4 secretion by the EPI cells and reduced expression of PE markers, such as GATA6 and SOX17 (Wicklow et al., 2014; Le Bin et al., 2014). Surprisingly, OCT4 has been reported to be required also cell-autonomously for the PE specification. It promotes expression of PE markers, such as PDGFR $\alpha$ and SOX17, downstream of FGF4 and ERK (Frum et al., 2013). Chimera complementation experiments revealed that wild-type ESCs aggregated with $\mathrm{Oct}^{-/}$embryos at the 8-cell stage fail to rescue PE phenotype, corroborating the notion that PE gene expression requires OCT4 cell-autonomously. Additional studies are needed to reconcile these results and support the idea of the potential dual role of OCT4 (both cell-autonomous and non-cellautonomous) in the PE formation.

Recently, it has been reported that FGF4 expression is also regulated by KLF5 (krüppel-like factor 5) (Fig. 2). Azami and coworkers (2017) have shown that depletion of KLF5 causes induction of FGF4 in the morula stage at E3.0, whereas the overexpression of KLF5 results in the reduction of FGF4 amount in blastocysts at E3.5. Thus, KLF5 acts to prevent untimely activation of the PEspecific genetic program by suppressing the FGF4/ERK pathway (Azami et al., 2017).

\section{Distinct roles of FGF receptors in the segregation of the epiblast and primitive endoderm cell lineages in mouse development}

It has long been uncertain, which FGFRs are responsible for the lineage specification in mouse preimplantation embryos. FGFR2 has been initially considered as the main receptor, cooperating with FGF4 and controlling emergence of the PE lineage within the ICM. Apart from FGFR2, FGFR1 is also expressed during the early preimplantation development. Fluorescently tagged reporters and transcriptomic analysis of single cells collected from E3.25 to E4.5 embryos enabled detection of intensive FGFR1 expression in all early ICM cells (E3.25, 32-cell stage) that coincides with the bimodal expression of FGF4 (Kang etal., 2013; Ohnishi et al., 2014). In addition to the pan-ICM expression, FGFR1 is also expressed at a comparable level in the TE lineage (Fig. 2), whereas FGFR2 expression is restricted to the extraembryonic lineages: TE and, at a noticeably lower level, PE (Molotkov et al., 2017). However, others claim that FGFR2 is detected only later in the development, at E3.5 (65-100 cells), in the PE-biased cells (Ohnishi et al., 2014; Kang et al., 2017) (Fig. 2).

Differential expression of FGFR1 and FGFR2 might reflect distinct roles of these two receptors during the cell fate specification. Several studies have provided conflicting evidence regarding the phenotype of $\mathrm{Fgfr}^{-/}$embryos. Some of them suggest that deletion of Fgfr2 leads to the embryonic lethality at E10.5 associated with defects in placenta and limb development (Xu et al., 1998; Yu et al., 2003; Kang et al., 2017; Molotkov et al., 2017). In contrast, others have reported that Fgfr2 $^{-1}$ embryos die at the periimplantation stage (Arman et al., 1998; Blak et al., 2007). These conflicting data suggest that other FGFRs can compensate for the lack of FGFR2 in the mouse embryo, FGFR1 being a likely candidate. Indeed, it has been shown that while the absence of FGFR2 does not reduce the number of PE cells (Kang et al., 2017; Molotkov et al., 2017), the deletion of Fgfr1 at least partially disrupts the PE development in blastocysts (Kang et al., 2017; Molotkov et al., 2017). Complete inhibition of the PE formation was observed only after simultaneous ablation of Fgfr1 and Fgfr2 genes (Kang et al., 2017; Molotkov et al., 2017). Similarly to Fgf4 ${ }^{-/}$embryos, recent 
studies on Fgfr1 ${ }^{-/}$and Fgfr2 ${ }^{-/}$mutants have demonstrated that expression of GATA6 is induced in 8- to 16-cell embryos but not maintained in the absence of FGF signaling components (Kang et al., 2017; Molotkov et al., 2017). It has been observed that after FGF4 treatment neither Fgfr $1 \%$, nor Fgfr 1 \%; Fgfr ${ }^{-/}$double mutant blastocysts are able to convert all the ICM cells to PE. Only in the Fgfr2- blastocysts FGF4 treatment induces ICM differentiation toward the PE fate (Kang et al., 2017; Molotkov et al., 2017). These results demonstrate that FGFR1 receptor plays a superior role in the PE formation in a mouse embryo. Indeed, FGFR1 expression starts to increase at the early blastocyst stage, at the time when the fate decision is being made, whereas PE-biased expression of FGFR2 is initiated at the mid blastocyst stage, i.e., at the time when ICM cells are already lineage-biased. Such timing of FGFR1 expression confirms its crucial role in the ICM cell fate determination. In contrast, it has been proposed that FGFR2 regulates survival and proliferation of the PE cells rather than the cell fate specification (Molotkov et al., 2017).

Among the other FGF receptors, FGFR3 and FGFR4 are only detected in committed PE cells at the late blastocyst stage ( $>100$ cells) (Ohnishi et al., 2014; Kang et al., 2017), suggesting that these receptors are not essential in establishment of the PE and EPI lineages within the ICM.

\section{The role of FGF4/ERK pathway in maturation of the mouse epiblast}

Apart from a well-known role in the PE specification and maintenance, the FGF4/ERK pathway seems to have an unexpected role in the EPI maturation. Kang and co-workers have demonstrated that, in contrast to the wild-type ICM cells in E4.5 mouse embryos, $\mathrm{Fgf4}^{-/} \mathrm{ICM}$ cells maintain a high level of NANOG expression (Kang et al., 2013), which is also a hallmark of embryos cultured in the presence of FGF signaling inhibitors (Nichols et al., 2009b). This observation suggests that the EPI cells in mutant embryos might remain in a naïve state of pluripotency, and thus are unable to enter the maturation program, which normally takes place after implantation (Kang et al., 2013). These findings are in line with the results of Ohnishi and colleagues, who employed the method of transcriptome analysis of single wild-type and $\mathrm{Fgf4}^{-/}$mutant ICM cells of E3.5 and E4.5 mouse embryos. They have shown that transcriptional profile of the ICM cells devoid of FGF4 is significantly distinct from the wild-type EPI cells, implying that manifestation of the EPI gene expression pattern is halted in the absence of FGF4 (Ohnishi et al., 2014). Such cells do not represent the bona fide EPI lineage and are unable to mature by downregulating NANOG expression (Ohnishi et al., 2014). The fact that differentiation of EPI cells into the three germ layers is arrested in $\mathrm{Fgf4}^{-/}$mutants shows that FGF4/ERK signaling pathway plays a critical role in maturation of this lineage. The recent report by Kang and colleagues has supported this view and shed new light on the mechanism of the EPI differentiation (Kang et al., 2017). The authors have shown that until the late blastocyst stage EPI cells in the Fgfr $^{1 \%}$; Fgfr2- double knockout embryos manifest more robust levels of NANOG expression than the wild-type EPI cells. However, inter-

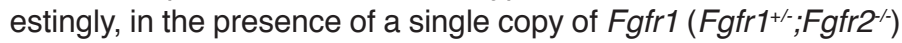
embryos display a wild-type level of NANOG expression in the ICMs. Moreover, embryos with $\mathrm{Fgfr}^{+/-}$or $\mathrm{Fgfr}^{-/}$backgrounds, possessing both copies of Fgfr1, manifest a reduction of NANOG expression in the $\mathrm{EPI}$, compared to the embryos possessing only a single Fgfr1 copy (i.e., Fgfr ${ }^{+/ /}$;Fgfr2 ${ }^{+/}$or Fgfr ${ }^{+/ /} ; F_{F f r 2}^{-/}$). Therefore, collectively, FGF4/ERK signaling operating via FGFR1 seems to play critical role in maturation of EPI lineage (Kang et al., 2017).

Surprisingly though, all the above findings are in a sharp contrast to the results reported by Nichols and co-workers (2009b). Here, the authors established ESCs colonies from ICMs of mouse embryos cultured from the 8-cell stage onward in medium enriched with inhibitors of FGF/ERK signaling pathway. They reported that such ICM cells are able to develop into a differentiated epiblast in chimera assays. Moreover, cells obtained from female embryos cultured in the presence of inhibitors resume the expression of the previously inactive paternal $\mathrm{X}$ chromosome, which is a characteristic trait of the differentiated epiblast (Nichols et al., 2009b). These discrepancies can be most likely explained by a different methodological approach applied in the studies. It seems, that pharmacological inhibition has only a transient effect, which is incomparable with the stable impact generated by the gene ablation.

According to the current knowledge, a new model for the establishment of both EPI and PE in a mouse blastocyst has been proposed, highlighting distinct roles of FGFR1 and FGFR2 in this process (Fig. 2). Initially, at E3.0-E3.25 all ICM cells express both EPI and PE markers (NANOG and GATA6, respectively), as well as FGFR1 (Plusa et al., 2008; Ohnishi et al., 2014) (Fig. 2). At some point, a subset of ICM cells starts producing FGF4 signal that is transduced through FGFR1 in all ICM cells to maintain NANOG expression at the physiological level and promote GATA6 expression (Kang et al., 2017; Molotkov et al., 2017) (Fig. 2). Interestingly, this initial decision of the ICM cells to become either EPI or PE seems to be independent of the FGF signaling pathway (Kang et al., 2013; Molotkov et al., 2017). Although Fgf4 is the first gene displaying a bimodal expression within the early ICM, the questions, why this ligand is expressed in just a few ICM cells and whether its expression is stable or fluctuates, require further studies. The recent report of Mistri et al., has indicated SOX2 and its increasing expression level in the emerging inner cells as the main driver of the earliest heterogeneity within the ICM (Mistri et al., 2018). Regardless of the FGFR1 expression, a subpopulation of ICM cells starts to express FGFR2 (Kang et al., 2017). In these cells GATA6 expression is maintained, leading to NANOG downregulation and activation of the PE program (Kang et al., 2017; Molotkov et al., 2017) (Fig. 2). As the development progresses, sustained FGF signaling is also required for maturation of the $\mathrm{EPI}$ lineage, i.e., exit from the naïve state of pluripotency and initiation of gastrulation.

Despite the consistent evidence for the role of FGF4/ERK signaling in EPI and PE establishment, some questions, e.g., the potential interplay with other signaling pathways, are still waiting for the answer. Recently, a sequential role for the FGF4 and PDGF $\alpha$ signaling pathways in establishing the cell fates has been proposed (Molotkov and Soriano, 2018). Analysis of the double mutants phenotype has provided evidence that FGFR1-mediated ERK signaling is involved in the PE specification, whereas PDGFR $\alpha$ and possibly FGFR2 - mediated PI3K signaling controls survival and proper positioning of the PE cells in the embryo (Molotkov and Soriano, 2018).

\section{The function of FGF/ERK signaling in mouse trophectoderm development}

The expression of FGFRs has been also detected in the TE cells (Arman et al., 1998; Haffner-Krausz et al., 1999; Ohnishi et 
al., 2014). Thus, it has been speculated that ICM-derived FGF4 might be a paracrine-acting growth factor affecting not only the PE development, but also regulating the adjacent polar TE via the ERK signaling pathway. This hypothesis has been supported by a report showing that Fgf4-/- mouse embryos manifest reduced expression of lineage-specific markers, such as FGFR2 in TE at E4.5. The authors therefore suggested that FGF4 is required for both PE and TE lineage development and differentiation beyond the implantation stage (Goldin and Papaioannou, 2003). However, many reports have shown that, in contrast to the PE formation, there is no convincing evidence that specification of the TE depends on the FGF4/ERK signaling. Treatment of zygotes with inhibitors of this pathway does not impede cavitation and hatching of the embryos. Moreover, cells of the outer epithelial layer express markers specific for TE, such as CDX2 and EOMES (eomesodermin) (Nichols et al., 2009b). Instead, it has been observed that inhibition of the FGF4/ERK pathway results in the reduced number of TE cells comparing to the control embryos. The same phenotype was observed when analyzing $\mathrm{Fgfr}^{-1-}$ and Fgfr2-- double mutants (Molotkov et al., 2017). While the formation of TE is not generally impaired in these mutants, the proportion of cells contributing to this lineage is decreased compared to the wild-type or single mutant embryos (Kang et al., 2017; Molotkov et al., 2017), implying the involvement of this signaling pathway in the expansion rather than specification of the TE. This has been additionally supported by the observation that addition of recombinant FGF4 to mouse blastocysts outgrowths (Chai et al., 1998; Leunda-Casi et al., 2001) or extraembryonic ectoderm cells isolated from E5.5 embryos (Nichols et al., 1998) suppresses TE differentiation into trophoblast giant cells and promotes the maintenance and expansion of diploid population of stem cells residing in the polar trophectoderm of implanting blastocysts.

Surprisingly, Lu and co-workers have reported that although embryos treated with MEK inhibitor from the morula stage onwards do not manifest any aberrations in the TE development, inhibition of the ERK signaling in embryos at 8-cell stage onwards attenuates CDX2 expression, halts cavitation and delays the embryo development (Lu et al., 2008). As it has turned out, in the 8-cell embryos ERK2 shows polarized distribution at the apical domain, but at the later stages it is distributed uniformly. Therefore, probably not only the presence of the ERK signaling components but also their proper localization during the course of development is important for maintaining the TE identity.

Moreover, a recent work by Kurowski and co-workers has shed new light on the role of FGF signaling in TE development and differentiation (Kurowski et al., 2019). The authors showed that $\mathrm{Fgfr}^{-/-}$embryos fail to downregulate CDX2 in the mural TE, which is critical for differentiation of TE lineage into giant cells and thus assuring proper implantation. What is more, TE cells of such mutant embryos, resembling the phenotype of CDX2 null embryos, manifest abnormal polarity indicated by aberrant localization of E-cadherin and show an increased apicobasal distance, which altogether might be the cause of the observed peri-implantation lethality of Fgfr $1^{-/}$embryos. Therefore, FGFR1 appears as a vital player in TE differentiation and post-implantation development (Kurowski et al., 2019).

To sum up, function of the FGF4/ERK signaling in the TE appears to be rather ambiguous and calls for further detailed studies. It is also possible that other members of the FGF family or other than ERK1/2 MAP kinases are important for specification of the TE lineage in mammalian embryos. Indeed, it has been demonstrated that FGF2 secreted by TE cells binds to FGFR2 present in their cell membrane and activates the downstream $\mathrm{PKC/p38}$ pathway, modulating blastocyst formation (Yang et al., 2015).

\section{FGF signaling and species-specific differences in mammalian embryo development}

Formation of the blastocyst is morphologically highly conserved among different mammalian species. Mouse is considered to be a model organism for the molecular and cellular events during the preimplantation embryo development. However, some variability regarding preimplantation developmental kinetics, timing of the lineage-associated transcription factor expression, implantation etc. exists among mammals, which may lead to a diverse regulation of these essential developmental events.

Although the expression of NANOG and GATA6 markers appears to be generally conserved in all mammals (Kuijk et al., 2012; Niakan and Eggan, 2013; Roode et al., 2012; Van der Jeught et al., 2013), the mechanisms governing the lineage specification within the ICM is diversified. Interestingly, recent studies have demonstrated that in rabbit FGFR2 is expressed at low levels during PE and EPI specification, whereas FGF4 and FGFR1 are clearly detectable throughout the period of the ICM differentiation (Piliszek et al., 2017). Similarly, in porcine blastocysts the expression of FGFR2 is not detected, while FGF4 and FGFR1 are highly expressed in the ICM, suggesting that the interaction between these two components drives the PE specification (Fujii et al., 2013). Localization of FGFRs was also investigated in bovine blastocysts. It has been demonstrated that FGFR2 and FGFR4 are detected exclusively in TE cells, whereas FGFR1 and FGFR3 are expressed in both TE and ICM in blastocysts (Ozawa et al., 2013). Additionally, all of the FGFRs are detected throughout preimplantation development of ovine embryos (Moradi et al., 2015). In turn, the expression pattern of FGFRs in human blastocysts is more uncertain. One set of studies has reported no detectable expression of FGFR1-4 in human blastocysts and robust expression of FGFR1-2, as well as a low level of FGFR3 in human placenta at $6^{\text {th }}$ week of gestation (Kunath et al., 2014). In contrast, another study has suggested that FGFR 1 is expressed much earlier during human embryo development, as it was observed in the majority of TE cells in blastocysts (Niakan and Eggan, 2013).

While the crucial role of FGF/ERK signaling during cell fate specification within the ICM has been proved in the mouse model, where advanced tools of genetic manipulation are available, comparatively little is known about its importance in other mammalian species, mainly due to the lack of methods to efficiently perturb gene expression. Chemical disruption of FGFR in porcine, bovine and marmoset embryos does not affect the hypoblast formation, whereas inhibition of the downstream pathway component, MEK, has only a partial effect on the ICM lineage commitment (Kuijk et al., 2012; Rodriguez et al., 2012; Boroviak et al., 2015). Inhibition of this signaling in bovine and marmoset embryos reduces but does not fully eliminate the GATA6-positive PE lineage (Kuijk et al., 2012; Boroviak et al., 2015). However, porcine and bovine embryos treated with FGF4 and heparin develop ICMs composed entirely of hypoblast cells, suggesting that FGF signaling directs GATA6 expression in these embryos (Kuijk et al., 2012; Rodriguez et al., 2012). Similarly, inhibition of FGFR has no effect on ovine 
embryo development, whereas FGF2 treatment significantly enhances expression of the hypoblast marker GATA4 and suppresses expression of the epiblast marker NANOG (Moradi et al., 2015). By contrast, in human embryos, inhibition of FGFR or MEK/ERK does not prevent formation of the GATA6-positive cells (Kuijk et al., 2012; Roode et al., 2012; Van der Jeught et al., 2013), but significantly increases the number of NANOG-positive cells in blastocysts (Van der Jeught et al., 2013). In rabbit, exogenous FGF4 induces the PE fate in all cells of the ICM, suggesting that the activity of this signaling pathway is required and sufficient to differentiate ICM cells towards the PE lineage. However, similarly to human embryos and in contrast to the mouse and bovine embryos, inhibition of the FGF4/ERK signaling is not sufficient to drive cell differentiation into EPI. Treatment of embryos with specific inhibitors blocking this pathway does not increase the number of SOX2-expressing cells, leading to the increased number of cells lacking both EPI and PE markers (SOX2 and SOX17-double negative cells). It also has no effect on the expression of GATA6, but severely affects the expression of the late hypoblast marker SOX17, indicating that maturation of this cell lineage requires FGF signaling pathway (Piliszek et al., 2017).

In conclusion, recent studies have provided accumulating evidence for intrinsic differences in early mammalian lineage specification between species. This raises a question what regulates segregation of the hypoblast and EPI precursors in non-rodent species. It is possible that some aspects of the ICM lineage commitment hinges on FGF signaling pathway. However, species-specific differences in the timing of the hypoblast formation and/or maturation and the period of responsiveness to the FGF signaling may account for the fact that this pathway does not impact cell fate specification as strongly as it does in mouse. On the other hand, since the knowledge on the FGF/ERK signaling in development of non-rodent mammals is based exclusively on the growth factor and inhibitor treatment approach, the true role of this pathway still remains an open question. Recent advances in gene editing, including CRISPR/Cas9 system, may facilitate functional studies of specific genes in mammalian species other than mouse. We anticipate that this promising gene editing technology coupled with other approaches, such as single-cell RNA-sequencing (RNAseq) and live imaging, will accelerate the discovery of the specific genes' role, allowing novel insight into similarities and differences between various mammalian species regarding lineage specification and its dependence on the FGF signaling.

\section{FGF4/ERK signaling pathway in embryo-derived stem cells: a reference to the embryos}

The first cell lineages in a blastocyst are a source of distinct stem cell types, which are considered to be a unique tool for studying embryonic development and differentiation in in vitro culture conditions. Embryonic stem cells (ESCs) are derived from the EPI (Evans and Kaufman, 1981; Martin, 1981), trophoblast stem cells (TSCs) originate from polar TE (Tanaka et al., 1998) and extraembryonic endoderm stem cells (XENCs) are isolated from PE (Kunath et al., 2005). All these stem cell lines are thought to faithfully recapitulate properties of the original embryo lineages and thus differ in their requirement for and responsiveness to the FGF4/ERK signaling pathway, during derivation and maintenance in vitro.

\section{Trophoblast stem cells}

Murine trophoblast stem cells represent an in vitro model of the TE. When injected into host blastocysts they give rise exclusively to the trophoblast lineage and, eventually, contribute to the fetal part of the placenta (Tanaka et al., 1998; Kubaczka et al., 2014). They can be derived from a polar TE from a blastocyst or from an extraembryonic ectoderm of early postimplantation embryos (Tanaka etal., 1998; Uy etal., 2002). For their derivation and proper maintenance, TSCs require MEF (mouse embryonic fibroblasts) as a feeder layer and supplementation of the culture medium with FGF4 (Tanaka et al., 1998). The feeder layer can be substituted with factors secreted by MEF cells, such as TGF $\beta 1$ (transforming growth factor $\beta 1$ ) and activin A (Erlebacher et al., 2004). In TSCs, FGF4 was reported to be the activator of the ERK cascade, playing a major role in regulating their proliferation and leading to the expression of essential trophoblast-specific markers, such as CDX2, EOMES, GATA3 (GATA binding protein 3), ETS2 (ETS proto-oncogene 2) or TCFAP2c (transcription factor AP-2, gamma) (Kuckenberg et al., 2011). Function of the FGF4/ERK transduction pathway has been highlighted by experiments, in which, upon withdrawal of FGF4 from the medium, TSCs manifested a rapid decline in their proliferation rate and ability to differentiate into giant cell-like cells (Tanaka et al., 1998) or the labyrinth trophoblast cells (Natale et al., 2009). Moreover, using inhibitors of the FGF/ ERK signaling pathway, such as FGFR or MEK, it has been shown that attenuation of this signal leads to down-regulation of the TSC markers, such as SOX2, ESRR $\beta$ (estrogen related receptor beta), CDX2, ELF5 (E74-like factor 5) and EOMES (Adachi et al., 2013; Latos et al., 2015). Interestingly, in these conditions, expression of ESRR $\beta$ decreased the most. ESRR $\beta$ has been identified as an early target of the FGF/ERK signaling (Latos et al., 2015) capable of driving together with SOX2, the self-renewal of TSCs (Adachi et al., 2013). The notion that endogenous FGF4 signaling is dispensable for derivation of undifferentiated TSCs colonies was also supported by Kang and co-workers, who successfully established and further propagated seven bona fide $\mathrm{Fgf4}^{-/ \mathrm{TSC}}$ lines in culture medium supplemented with exogenous FGF4 (Kang et al., 2013). Moreover, TSCs maintenance and proliferation rate depends also on the background of the embryo. Ogawa and co-workers demonstrated that some of the murine TSCs derived from androgenetic embryos were able to self-propagate in the absence of FGF4 (Ogawa et al., 2016).

Interestingly, a recent report by Kurowski et al. highlights the vital role of FGF receptors in derivation and maintenance of mouse TSCs (Kurowski et al., 2019). TSC lines can be established and propagated in the absence of both functional copies of FGFR1 or FGFR2, however, Fgfr1-/- TSCs lineages manifest defective differentiation potential as indicated by significantly lower expression of differentiation markers, such as DLX3 (distal-less homeobox 3), HAND1 (heart and neural crest derivatives expressed 1) and MASH2 also known as ASCL2 (achaete-scute family bHLH transcription factor 2). However, despite using several approaches, the authors were not able to establish TSCs from double FGFR1 and FGFR2 mutants. Therefore, it seems that while the absence of one or the other FGFR can be somehow compensated by one another, the loss of both FGF receptors does not allow derivation and self-propagation of mouse TSCs (Kurowski et al., 2019).

Over the years TSCs from other mammalian species have been established, including rhesus monkey (Vandevoort et al., 2007), 
common vole (Grigor'eva et al., 2009), rat (Asanoma et al., 2011), rabbit (Tan et al., 2011) and human (Okae et al., 2018). Nevertheless, except for rat TSCs that rely on FGF4 signaling since they cease to proliferate and start differentiating upon withdrawal of this growth factor from the culture medium (Asanoma et al., 2011), TSCs from all of the above species have not been reported to depend on the FGF4/ERK signaling pathway.

\section{Extraembryonic endoderm stem cells}

XENCs can be established either from a blastocyst PE (Kunath et al., 2005), or from postimplantation (E5.5-E6.5) embryos (Lin et al., 2016). They comprise two populations of morphologically heterogeneous cells maintaining very little cell-cell contact, namely small, round and highly retractile cells and epithelial-like cells (Kunath et al., 2005). XENCs represent an in vitro model of PE and its derivatives, such as visceral and parietal endoderm. However, after injection into host embryos these cells tend to colonize parietal rather than visceral endoderm (Kruithof-de Julio et al., 2011), contributing to the yolk sac of the chimeric embryos (Kunath et al., 2005; Kruithof-de Julio et al., 2011). As the in vitro counterparts of PE they express proteins typical for the lineage of their origin, such as GATA4, GATA6, SOX7, SOX17 and DAB2 (disabled 2, mitogen-responsive phosphoprotein) (Kunath et al., 2005; Lin et al., 2016), as well as visceral endoderm markers, such as ApoE (apolipoprotein E), AMOT (angiomotin) and HEX (hematopoietically expressed homeobox), which are determinants of their multipotent state (Spruce et al., 2010).

Although FGF4 is required for PE formation in an embryo and the first XENCs colonies were established in the presence of exogenous FGF4 in the culture medium (Kunath et al., 2005), Kang and co-workers have demonstrated that endogenous FGF4 is irrelevant for the derivation of novel XENCs lines and for maintenance of the established XENCs colonies (Kang et al., 2013). They managed to isolate and maintain XENCs from Fgf4-/ mutants supplementing the culture medium with FGF4 (Kang et al., 2013). Instead, the proper self-renewal of these cells has been reported to rely on the PDGF (platelet derived growth factor) - dependent activation of MAPK cascade (Artus et al., 2013). However, recently, Lin and co-workers have derived and maintained PDGF-deficient XENCs lines from both pre- and postimplantation mouse embryos, demonstrating that PDGF is negligible in establishment and selfrenewal of these cells (Lin et al., 2017).

Moreover, the MAPK pathway operating in XENCs has been reported to be regulated by miRNA network, which maintains XENCs identity in terms of their multipotency and self-renewal by inhibition of the negative regulators of this signaling cascade (Spruce et al., 2010). Apart from mice, XEN-like cells have been established only for rat (Galat et al., 2009), however, their establishment and maintenance do not seem to depend on FGF4 signaling.

\section{Embryonic stem cells}

The first ESCs lines were expanded on a MEF feeder layer and in the presence of fetal bovine serum, which provides a broad spectrum of hormones, essential nutrients and growth factors (Gstraunthaler, 2003). Several years of research have revealed how signaling cascades integrate with the transcription factors and govern the balance between ESCs self-renewal and differentiation. Ying and co-workers have shown that self-renewal of these cells depends not only on the activation of LIF (leukemia inhibitory fac- tor) and BMP (bone morphogenetic protein) signaling pathways (Niwa et al., 1998; Ying et al., 2003), but can be also maintained by inhibition of the differentiation-inducing signals (Ying et al., 2008). The combination of three inhibitors - SU5402 for the FGFR, PD184352 for MEK and CHIR99021 for GSK3 (glycogen synthase kinase 3 ), which is a component of the WNT (wingless integration) pathway, enabled not only more efficient derivation of ESCs from the 129 mouse strain, but also establishment of ESCs lines from less permissive mouse strains (Ying et al., 2008; Nichols et al., 2009a; Reinholdt et al., 2012), as well as from rats (Li et al., 2008).

Although ESCs are derived from the EPI, produce FGF4 (Schoorlemmer and Kruijer, 1991) and activate FGF/ERK signaling in an autocrine manner, it has been implicated that FGF4 is dispensable for propagation of the undifferentiated mouse ESCs. Indeed, the loss of both functional copies of Fgf4 gene in murine ESCs does not impair their self-renewal abilities, indicating that FGF4 is not an ES-specific growth factor (Wilder et al., 1997). On the other hand, some reports have shown that the ERK signaling itself is in fact indispensable for the genomic stability and self-renewal of murine ESCs, since ERK depleted ESCs are not able to be maintained in the in vitro culture (Chen et al., 2015). This finding is in line with the work of Kook and colleagues, who have demonstrated that in the presence of LIF, the addition of exogenous FGF4 promotes proliferation of mouse ESCs (Kook et al., 2013). Therefore, perhaps a minimal level of autocrine FGF4/ERK signaling is yet beneficial for these cells.

Embryonic stem cells are characterized with the highest developmental potential among other blastocyst-derived stem cells. They are pluripotent, which means that upon injection into host embryos they are able to contribute to the epiblast and give rise to all cell types of the resulting chimeras (Bradley and Robertson, 1986; Beddington and Robertson, 1989; Poueymirou et al., 2007). Although the exact role of FGF4/ERK signaling in self-renewal of mouse ESCs seems ambiguous, several reports have shown that activation of this pathway is generally associated with promoting the transition of mouse ESCs from their naïve state of pluripotency into a state primed for differentiation in an ERK-dependent fashion. It has been shown that ESCs with mutations in genes involved in biosynthesis of heparan sulfate proteoglycans, which are co-receptors of FGF ligand, were unable to enter the primed state (Lanner et al., 2010). Moreover, FGF signaling prevents the already primed cells from spontaneous reverting to the naïve pluripotency state by suppressing expression of the naïve pluripotency factors, such as KLF4 (Kruppel-like factor 4) (Guo et al., 2009). Such primed ESCs, known as EpiSCs (epiblast-derived stem cells), represent the later stage of development and can be derived from the epiblast of postimplantation embryos (Brons et al., 2007; Tesar et al., 2007). Although, similarly to ESCs, they express the core pluripotency factors, such as OCT4, NANOG and SOX2, they also manifest expression of early differentiation markers (Nichols and Smith, 2009) and are not capable of contributing to the EPI of the chimeric blastocysts (Guo et al., 2009, Tesar et al., 2007). Moreover, their self-renewal has been found to strictly depend on activin A signaling, which directly activates expression of Nanog (Greber et al., 2010). On the other hand, a report by Joo and co-workers has shown that FGF4 is a key factor bringing EpiSCs into a more naïve state and enabling the formation EpiSCs lines capable of chimera-forming (Joo et al., 2014).

Moreover, the fact that murine ESCs have been reported to 
comprise heterogeneous populations of cells, which differ in expression of pluripotency factors, such as NANOG (Singh et al., 2007), DPPA3 (developmental pluripotency-associated 3, also known as Stella) (Hayashi et al., 2008) or ZFP42 (zinc finger protein 42 homolog) (Toyooka et al., 2008) or even express markers typical for differentiated cells, such as GATA6 (Singh et al., 2007), suggests a role of FGF/ERK cascade in modulating the shades of ESCs pluripotency. Indeed, both inhibition and stimulation of the pathway can change proportions of the given group within the cultured cells, as it has been reported for the HEX (hematopoietically expressed homeobox)-expressing ESCs sub-population, primed for the PE fate (Canham et al., 2010).

FGF4 signaling has been found also to drive the differentiation of murine ESCs into neural and mesodermal lines, since both the genetic knockouts of the FGF4/ERK pathway components or their pharmacological inhibition impairs this process (Kunath et al., 2007; Stavridis et al., 2007). Although in the absence of LIF these cells express FGF5, a marker of the differentiated EPI, they retain the expression of pluripotency markers, such as OCT4, NANOG and REX1, and cannot enter the truly differentiated state. Since the ESCs Fgf4-/ phenotype can be rescued upon addition of exogenous FGF4, these results collectively demonstrate that the autocrine FGF4 signaling activates differentiation of ESCs (Kunath et al., 2007; Stavridis et al., 2007). These findings are in line with a recent report showing that FGF4/ERK signaling is required for induction of neural differentiation (Song et al., 2018). On the other hand, some reports seem to contradict these results, showing that although FGF4/ERK signaling impedes ESCs self-renewal, it is dispensable for the three germ layer specification and postulating that neural differentiation is a default fate of these cells and occurs naturally despite impaired ERK signaling (Hamilton et al., 2013). Instead, the prolonged activation of this pathway has been reported to cause a definite differentiation of mouse ESCs into the PE lineage by de-repression of GATA6 expression (Hamilton and Brickman, 2014).

Interestingly, a recent work of Molotkov and co-workers (2017) gave a new insight into the mechanism of FGF4/ERKmediated differentiation in ESCs. The authors generated ESCs lines from Fgfr $^{+++} ; \mathrm{Fgfr}^{+/+}, \mathrm{Fgfr}^{+/-} ; \mathrm{Fgfr}^{-/-}, \mathrm{Fgfr}^{-/-} ; \mathrm{Fgfr}^{+/-}$and $\mathrm{Fgfr}^{-/-} ; \mathrm{Fgfr}^{-/-}$mouse embryos and analyzed the role of the FGF signaling in conversion of ESCs into neuronal and mesodermal lineages. They found that although $\mathrm{Fgfr}^{+/+} ; \mathrm{Fgfr}^{+/+} \mathrm{ESCs}$ can readily differentiate into neurons after 10 days of culture, the Fgfr $^{-1-} ;$ Fgfr2 $^{-/}$ESCs are not able to initiate conversion into neurons, as well as non-neural ectoderm and mesoderm, which has been confirmed by a high level of OCT4 expression and practically undetectable levels of cadherin 1 and PDGFR $\alpha$ markers of ectodermal and mesenchymal cells (Molotkov et al., 2017). Moreover, the Fgfr ${ }^{+/-} ;$Fgfr2 $^{-/-}$ESCs manifested robust neuronal induction, whereas the $\mathrm{Fgfr}^{-1-} ; \mathrm{Fgfr}^{+/-}$ESCs failed to transform. These findings indicate therefore, that FGFR1, rather than FGFR2, is critical for ESCs differentiation. Molotkov and colleagues obtained analogous results in their experiments on mutant ESCs subjected to conversion into the XENC lines upon retinoic acid and activin A treatment (Molotkov et al., 2017). Although the Fgfr1 $^{+/-} ;$Fgfr2 $^{-/-}$ESCs readily converted into XENC lines upon such treatment, the $\mathrm{Fgfr}^{-/-} ; \mathrm{Fgfr}^{+/-}$cells were arrested in their naïve pluripotent state, manifesting stable expression of OCT4 and NANOG. Similarly, mutant $\mathrm{Fgfr}^{-1-} ; \mathrm{Fgfr}^{-/-}$cells also exhib- ited elevated expression of OCT4 and NANOG, as well as other pluripotency markers, such as KLF4 and REX1. Moreover, while the proliferation rate was similar in wild-type and $\mathrm{Fgfr}^{-1-} ; \mathrm{Fgfr}^{-1-}$ ESCs, the Fgfr1 $^{-/-} ; \mathrm{Fgfr}^{-/-}$cells converted vastly into apoptotic bodies upon the differentiation stimuli (Molotkov et al., 2017). These findings suggest that a single copy of Fgfr1 is critical for ESCs to enter the differentiation program and that although Fgfr deficient ESCs may initiate XENCs differentiation, they fail to maintain this process undergoing cell death.

Apart from mice and rats, ESCs have been derived from primates, such as monkeys (Thomson et al., 1995; Thomson et al., 1996) and humans (Thomson et al., 1998), however, their maintenance does not require the culture conditions applied to rodent ESCs. Although human ESCs have the ability to contribute in teratoma assays to tissues derived from all three germ layers, they do not fully reflect the properties of the naïve rodent ESCs. In fact, they resemble more the mouse EpiSCs in terms of the flat morphology of their in vitro colonies, inactivation of the X chromosome in female embryo-derived cell lines, dependence on TGF $\beta$ / activin signaling for self-renewal and differentiation in response to BMP4 (Hanna et al., 2010). These differences raise a question whether derivation of bona fide naïve ESCs from non-rodent species depends on other factors than FGF4 signaling. A report by Mayshar and co-workers has shed new light on this case, postulating that FGF4 is an autocrine-acting factor maintaining proper self-renewal of human ESCs. Moreover, they have also identified a novel, truncated FGF4 splice isoform, FGFsi, which is an antagonist of the full-length FGF4 impairing the FGF4 signaling and promoting differentiation of human ESCs (Mayshar et al., 2008).

\section{Conclusions and perspectives}

Derivation of lineage-specific stem cells has opened up the opportunity to mimic early developmental events in vitro. For example, using engineered ESCs as a model Schröter et al., have revealed that FGF/ERK signaling may have a two-step role in the EPI vs. PE fate decision (Schröter et al., 2015). In the first step, inhibition of this pathway is required to make PE-like gene expression program accessible for activation of GATA transcription factors. Subsequently, ERK signaling sets the threshold concentration of GATA factors, which is required to trigger the PE differentiation program and, as a consequence, determines the proportion of cells differentiating into particular lineages (Schröter et al., 2015).

Although ESCs, like EPI cells, seem to exhibit similar response (i.e., differentiation) to the FGF signaling, other stem cells do not directly recapitulate the signaling properties of their lineage of origin. FGF4 is required for PE formation, but is dispensable for XENCs propagation. On the other hand, TSCs maintenance requires FGF4, however, there is no evidence of the FGF4 role in establishment of the embryonic TE lineage. These disparities between embryonic cell lineages and the corresponding stem cells have raised the question whether the same rules apply in in vivo and in vitro conditions and whether blastocyst-derived stem cells are true equivalents of the cell lineages they originate from. Therefore, the data based on the stem cell models and their extrapolation to the in vivo situation require thorough verification by other approaches. Emerging tools, such as an ESC line and a derivative mouse line, carrying an $\mathrm{H} 2 \mathrm{~B}-$ Venus fusion knocked into the Spry4 (an early FGF/ERK pathway target) locus 
(Morgani et al., 2018), will definitely provide novel insights into the spatiotemporal dynamics of the FGF/ERK signaling pathway during mammalian development, thus uncovering yet unknown aspects of its regulation.

In summary, FGF ligands and their receptors are required pleiotropically during mouse embryonic development, providing a mechanism for the spatial and temporal control of cell differentiation. Deregulated cell-to-cell communication can result in disorders and failure of the embryogenesis. However, differences identified in the function of the FGF pathway in mouse vs. non-rodent mammals make it difficult to extrapolate findings on lineage allocation from mice to the other species. Understanding the source and significance of these disparities, with the aid of novel technologies, such as CRISPR/Cas9, and defining the cross-talk between the FGF4 cascade and other signaling pathways will be the biggest challenge for the coming years.

\section{Acknowledgments}

The authors would like to apologize for any potential omission of the relevant literature. It would have been unintended. The authors thank Professor Marek Maleszewski for critical comments. During the preparation of this work Aneta Suwińska and Anna Soszyńska were supported by a grant of SONATA (2014/15/D/NZ3/02435) and Katarzyna Klimczewska was supported by a grant PRELUDIUM (142017/27/N/NZ3/00625) from the National Science Center (Poland).

\section{References}

ADACHI K, NIKAIDO I, OHTA H, OHTSUKA S, URA H, KADOTA M, WAKAYAMA T, UEDAHR, NIWAH (2013). Context-dependent wiring of Sox2 regulatory networks for self-renewal of embryonic and trophoblast stem cells. Mol Cell 52: 380-392.

ARMAN E, HAFFNER-KRAUSZ R, CHEN Y, HEATH JK, LONAI P (1998). Targeted disruption of fibroblast growth factor (FGF) receptor 2 suggests a role for FGF signaling in pregastrulation mammalian development. Proc Natl Acad Sci USA 95: 5082-5087.

ARTUS J, KANG M, COHEN-TANNOUDJI M, HADJANTONAKIS AK (2013). PDGF signaling is required for primitive endoderm cell survival in the inner cell mass of the mouse blastocyst. Stem Cells 31: 1932-1941.

ASANOMAK, RUMI MA, KENT LN, CHAKRABORTY D, RENAUD SJ, WAKE N, LEE DS, KUBOTA K, SOARES MJ (2011). FGF4-dependent stem cells derived from rat blastocysts differentiate along the trophoblast lineage. Dev Bio/351: 110-119.

AZAMI T, WAKU T, MATSUMOTO K, JEON H, MURATANI M, KAWASHIMA A, YANAGISAWAJ, MANABE I, NAGAI R, KUNATHT, NAKAMURAT, KURIMOTOK, SAITOU M, TAKAHASHI S, EMAM (2017). KIf5 maintains the balance of primitive endoderm versus epiblast specification during mouse embryonic development by suppression of Fgf4. Development 144: 3706-3718.

BEDDINGTON RS, ROBERTSON EJ (1989). An assessment of the developmental potential of embryonic stem cells in the midgestation mouse embryo. Development 105: 733-737.

BÉLANGER LF, ROY S, TREMBLAY M, BROTT B, STEFF AM, MOURAD W, HUGO P, ERIKSON R, CHARRON J (2003). Mek2 is dispensable for mouse growth and development. Mol Cell Biol 23: 4778-4787.

BESSONNARD S, COQUERAN S, VANDORMAEL-POURNIN S, DUFOUR A ARTUS J, COHEN-TANNOUDJI M (2017). ICM conversion to epiblast by FGF/ ERK inhibition is limited in time and requires transcription and protein degradation. Sci Rep 7: 12285.

BESSONNARD S, DE MOT L, GONZE D, BARRIOL M, DENNIS C, GOLDBETER A, DUPONT G, CHAZAUD C (2014). Gata6, Nanog and Erk signaling control cell fate in the inner cell mass through a tristable regulatory network. Development 141: 3637-3648.

BIRNBAUM D, POPOVICI C, ROUBIN (2005). A pair as a minimum: the two fibroblast growth factors of the nematode Caenorhabditis elegans. Dev Dyn 232: 247-255.

BISSONAUTH V, ROY S, GRAVEL M, GUILLEMETTE S, CHARRON J (2006). Requirement for Map2k1 (Mek1) in extra-embryonic ectoderm during placento- genesis. Development 133: 3429-3440.

BLAKAA, NASERKET, SAARIMAKI-VIREJ, PELTOPUROP, GIRALDO-VELASQUEZ $\mathrm{M}$, VOGT WEISENHORN DM, PRAKASH N, SENDTNER M, PARTANEN J, WURSTW (2007). Fgfr2 and Fgfr3 are not required for patterning and maintenance of the midbrain and anterior hindbrain. Dev Biol 303: 231-243.

BOROVIAK T, LOOS R, LOMBARD P, OKAHARA J, BEHR R, SASAKI E, NICHOLS J, SMITH A, BERTONE P (2015). Lineage-specific profiling delineates the emergence and progression of naive pluripotency in mammalian embryogenesis. Dev Cell 35: 366-363.

BOTTCHER RT, NIEHRS C (2005). Fibroblast growth factor signaling during early vertebrate development. Endocr Rev 26: 63-77.

BRADLEY A, ROBERTSON E (1986). Embryo-derived stem cells: a tool for elucidating the developmental genetics of the mouse. Curr Top Dev Biol 20: 357-371.

BREWER JR, MAZOT P, SORIANO P (2016). Genetic insights into the mechanisms of Fgf signaling. Genes Dev 30: 751-71.

BRONS IG, SMITHERS LE, TROTTER MW, RUGG-GUNN P, SUN B, CHUVA DE SOUSA LOPES SM, HOWLETT SK, CLARKSON A, AHRLUND-RICHTER L, PEDERSEN RA, VALLIER L (2007). Derivation of pluripotent epiblast stem cells from mammalian embryos. Nature 448: 191-195.

BURGAR HR, BURNS HD, ELSDEN JL, LALIOTI MD, HEATH JK (2002). Association of the signaling adaptor FRS2 with fibroblast growth factor receptor 1 (Fgfr1) is mediated by alternative splicing of the juxtamembrane domain. J Biol Chem 277: 4018-4023.

CANHAM MA, SHAROVAA, KOMS, BRICKMAN JM (2010). Functional heterogeneity of embryonic stem cells revealed through translational amplification of an early endodermal transcript. PLOS Biol 8: e1000379.

CHA H, LEE EK, SHAPIRO P (2001). Identification of a C-terminal region that regulates mitogen-activated protein kinase kinase-1 cytoplasmic localization and ERK activation. J Biol Chem 276: 48494-48501.

CHAI N, PATEL Y, JACOBSON K, MCMAHON J, MCMAHON A, RAPPOLEE DA (1998). FGF is an essential regulator of the fifth cell division in preimplantation mouse embryos. Dev Biol 198: 105-115.

CHAZAUD C, YAMANAKA Y (2016). Lineage specification in the mouse preimplantation embryo. Development 143: 1063-1074.

CHAZAUD C, YAMANAKA Y, PAWSON T, ROSSANT J (2006). Early lineage segregation between epiblast and primitive endoderm in mouse blastocysts through the Grb2-MAPK pathway. Dev Cell 10: 615-624.

CHELLAIAH AT, MCEWEN DG, WERNER S, XU J, ORNITZ DM (1994). Fibroblas Growth Factor receptor (FGFR) 3. Alternative splicing in immunoglobulin-like domain III creates a receptor highly specific for acidic FGF/FGF-1. J Biol Chem 269: 11620-11627.

CHEN H, GUO R, ZHANG Q, GUO H, YANG M, WU Z, GAO S, LIU L, CHEN L (2015) Erk signaling is indispensable for genomic stability and self-renewal of mouse embryonic stem cells. Proc Natl Acad Sci USA 112: 5936-5943.

CHEN H, MA J, LI W, ELISEENKOVA AV, XU C, NEUBERT TA, MILLER WT, MOHAMMADI M (2007). A molecular brake in the kinase hinge region regulates the activity of receptor tyrosine kinases. Mol Cell 27: 717-730.

CHENG AM, SAXTONTM, SAKAI R, KULKARNI S, MBAMALU G etal., (1998). Mammalian Grb2 regulates multiple steps in embryonic development and malignant transformation. Cell 95: 793-803.

CHUNG KC, GOMES I, WANG D, LAU LF, ROSNER MR (1998). Raf and fibroblast growth factor phosphorylate Elk1 and activate the serum response element of the immediate early gene pip92 by mitogen-activated protein kinase-independent as well as -dependent signaling pathways. Mol Cell Biol 18: 2272-2281.

EKEROT M, STAVRIDIS MP, DELAVAINE L, MITCHELL MP, STAPLES C, OWENS DM, KEENAN ID, DICKINSON RJ, STOREY KG, KEYSE SM (2008). Negativefeedback regulation of FGF signalling by DUSP6/MKP-3 is driven by ERK1/2 and mediated by Ets factor binding to a conserved site within the DUSP6/MKP-3 gene promoter. Biochem J 412: 287-298.

ERLEBACHER A, PRICE KA, GLIMCHER LH (2004). Maintenance of mouse trophoblast stem cell proliferation by TGF-beta/activin. Dev Biol 275: 158-169.

EVANS MJ, KAUFMAN MH (1981). Establishment in culture of pluripotential cells from mouse embryos. Nature 292: 154-156.

FELDMAN B, POUEYMIROU W, PAPAIOANNOU VE, DECHIARA TM, GOLDFARB M (1995). Requirement of FGF-4 for postimplantation mouse development. Science 267: 246-249. 
FLAUMENHAFTR, MOSCATELLID, RIFKINDB (1990). Heparin and heparan sulfate increase the radius of diffusion and action of basic fibroblast growth factor. $J$ Cell Biol 111: 1651-1659.

FOEHR ED, RAFFIONI S, MURRAY-RUST J, BRADSHAW RA (2001). The role of tyrosine residues in fibroblast growth factor receptor 1 signaling in $\mathrm{PC} 12$ cells. Systematic site-directed mutagenesis in the endodomain. $J$ Biol Chem 276: 37529-37536.

FRANKENBERG S, GERBE F, BESSONNARD S, BELVILLE C, POUCHIN P, BARDOT O, CHAZAUD C (2011). Primitive endoderm differentiates via a three step mechanism involving Nanog and RTK signaling. Dev Cell 21: 1005-1013.

FRUM T, HALBISEN MA, WANG C, AMIRI H, ROBSON P, RALSTON A (2013). Oct4 cell-autonomously promotes primitive endoderm development in the mouse blastocyst. Dev Cell 25: 610-622.

FUJII T, SAKURAI N, OSAKI T, IWAGAMI G, HIRAYAMA H, MINAMIHASHI A, HASHIZUME T, SAWAIK (2013). Changes in the expression patterns of the genes involved in the segregation and function of inner cell mass and trophectoderm lineages during porcine preimplantation development. J Reprod Dev59: 151-158.

FURDUI CM, LEW ED, SCHLESSINGER J, ANDERSON KS (2006). Autophosphorylation of FGFR1 kinase is mediated by a sequential and precisely ordered reaction. Mol Cell 21: 711-717.

FÜRTHAUER M, LIN W, ANG SL, THISSE B, THISSE C (2002). Sef is a feedbackinduced antagonist of Ras/MAPK-mediated FGF signalling. NatCellBiol4:170-174.

GALAT V, BINAS B, IANNACCONE S, POSTOVIT L-M, DEBEB BG, IANNACCONE P (2009). Developmental potential of rat extraembryonic stem cells. Stem Cells Dev 18: 1309-1318.

GERBE F, COX B, ROSSANT J, CHAZAUD C (2008). Dynamic expression of Lrp2 pathway members reveals progressive epithelial differentiation of primitive endoderm in mouse blastocyst. Dev Biol 313: 594-602.

GOLDIN SN, PAPAIOANNOU VE (2003). Paracrine action of FGF4 during periimplantation development maintains trophectoderm and primitive endoderm. Genesis 36:40-47.

GOTOH N (2008). Regulation of growth factor signaling by FRS2 family docking/ scaffold adaptor proteins. Cancer Sci 99: 1319-1325.

GRABAREK JB, ZYZYŃSKA K, SAIZ N, PILISZEK A, FRANKENBERG S, NICHOLS J, HADJANTONAKIS AK, PLUSA B (2012). Differential plasticity of epiblast and primitive endoderm precursors within the ICM of the early mouse embryo. Development 139: 129-139.

GREBER B, WU G, BERNEMANN C, JOO JY, HAN DW, KO K, TAPIA N, SABOUR D, STERNECKERT J, TESAR P, SCHÖLER HR (2010). Conserved and divergent roles of FGF signaling in mouse epiblast stem cells and human embryonic stem cells. Cell Stem Cell 6: 215-226.

GRIGOR'EVAEV, SHEVCHENKOAI, MAZUROKNA, ELISAPHENKOEA, ZHELEZOVAAI, SHILOVAG, DYBAN PA, DYBANAP, NONIASHVILI EM, SLOBODYANYUK SY, NESTEROVA TB, BROCKDORFF N, ZAKIAN SM (2009). FGF4 independent derivation of trophoblast stem cells from the common vole. PLoS One 4: e7161.

GSTRAUNTHALER G (2003). Alternatives to the use of fetal bovine serum: serumfree cell culture. ALTEX 20: 275-281.

GUO G, HUSS M, TONG GQ, WANG C, LI SUN L, CLARKE ND, ROBSON P (2010). Resolution of cell fate decisions revealed by single-cell gene expression analysis from zygote to blastocyst. Dev Cell 18: 675-685.

GUO G, YANG J, NICHOLS J, HALL JS, EYRES I, MANSFIELD W, SMITH A (2009). KIf4 reverts developmentally programmed restriction of ground state pluripotency. Development 136: 1063-1069.

HADARI YR, GOTOH N, KOUHARA H, LAXI, SCHLESSINGER J (2001). Critical role for the docking-protein FRS2 alpha in FGF receptor-mediated signal transduction pathways. Proc Natl Acad Sci USA 98: 8578-8583.

HAFFNER-KRAUSZ R, GORIVODSKY M, CHEN Y, LONAI P (1999). Expression of Fgfr2 in the early mouse embryo indicates its involvement in preimplantation development. Mech Dev 85(1-2):167-172.

HAMILTON WB, BRICKMAN JM (2014). Erk signaling suppresses embryonic stem cell self-renewal to specify endoderm. Cell Rep 9: 2056-2070.

HAMILTON WB, KAJI K, KUNATH T (2013). ERK2 suppresses self-renewal capacity of embryonic stem cells, but is not required for multi-lineage commitment. PLOS One 8: e60907.

HANAFUSA H, TORII S, YASUNAGA T, NISHIDA E (2002). Sprouty1 and Sprouty2 provide a control mechanism for the Ras/MAPK signalling pathway. Nat Cell
Biol 4: 850-858.

HANNA J, CHENG AW, SAHA K, KIM J, LENGNER CJ, SOLDNER F, CASSADY JP, MUFFAT J, CAREY BW, JAENISCH R (2010). Human embryonic stem cells with biological and epigenetic characteristics similar to those of mouse ESCs. Proc Natl Acad Sci USA 107: 9222-9227.

HATANO N, MORI Y, OH-HORA M, KOSUGI A, FUJIKAWA T, NAKAI N, NIWA H, MIYAZAKI J, HAMAOKA T, OGATA M (2003). Essential role for ERK2 mitogenactivated protein kinase in placental development. Genes Cells 8: 847-856.

HAYASHI K, DE SOUSA LOPES SMC, TANG F, LAO K, SURANI MA (2008). Dynamic equilibrium and heterogeneity of mouse pluripotent stem cells with distinct functional and epigenetic states. Cell Stem Cell 3: 391-401.

HERR AB, ORNITZ DM, SASISEKHARAN R, VENKATARAMAN G, WAKSMAN G (1997). Heparin-induced self-association of fibroblast growth factor-2. Evidence for two oligomerization processes. J Biol Chem 272: 16382-16389.

JOHNSON DE, WILLIAMS LT (1993). Structural and functional diversity in the FGF receptor multigene family. Adv in Cancer Res 60: 1-41.

JOO JY, CHOI HW, KIM MJ, ZAEHRES H, TAPIA N, STEHLING M, JUNG KS, DO JT, SCHÖLER HR (2014). Establishment of a primed pluripotent epiblast stem cell in FGF4-based conditions. Sci Rep 4: 7477.

KALININA J, DUTTA K, ILGHARI D, BEENKEN A, GOETZ R, ELISEENKOVA AV, COWBURN D, MOHAMMADI M (2012). The alternatively spliced acid box region plays a key role in FGF receptor autoinhibition. Structure 20: 77-88.

KANG M, GARG V AND HADJANTONAKIS AK (2017). Lineage establishment and progression within the inner cell mass of the mouse blastocyst requires FGFR1 and FGFR2. Dev Cell 41: 496-510.

KANG M, PILISZEK A, ARTUS J, HADJANTONAKIS A-K (2013). FGF4 is required for lineage restriction and salt-and-pepper distribution of primitive endoderm factors but not their initial expression in the mouse. Development 140: 267-279.

KIM HJ, BAR-SAGI D (2004). Modulation of signalling by Sprouty: a developing story. Nat Rev Mol Cell Biol 5: 441-450.

KOOK SH, JEON YM, LIM SS, JANG MJ, CHO ES, LEE SY, CHOI KC, KIM JG, LEE JC (2013). Fibroblast growth factor-4 enhances proliferation of mouse embryonic stem cells via activation of c-Jun signaling. PLoS One 8: e71641.

KOUHARA H, HADARI YR, SPIVAK-KROIZMAN T, SCHILLING J, BAR-SAGI D, LAXI, SCHLESSINGER J (1997). A lipid-anchored Grb2-binding protein that links FGF-receptor activation to the Ras/MAPK signaling pathway. Cell 89: 693-702.

KOVALENKO D, YANG X, NADEAURJ, HARKINS LK, FRIESELR (2003). Sefinhibits fibroblast growth factor signaling by inhibiting FGFR1 tyrosine phosphorylation and subsequent ERK activation. J Biol Chem 278: 14087-14091.

KRAWCHUK D, HONMA-YAMANAKA N, ANANI S, YAMANAKA Y (2013). FGF4 is a limiting factor controlling the proportions of primitive endoderm and epiblast in the ICM of the mouse blastocyst. Dev Biol 384: 65-71.

KRUITHOF-DE JULIO M, ALVAREZ MJ, GALLI A, CHU J, PRICE SM, CALIFANO A, SHEN MM (2011). Regulation of extra-embryonic endoderm stem cell differentiation by Nodal and Cripto signaling. Development 138: 3885-3895.

KRUPA M, MAZUR E, SZCZEPAŃSKA K, FILIMONOW K, MALESZEWSKI M, SUWIŃSKA A (2014). Allocation of inner cells to epiblast vs primitive endoderm in the mouse embryo is biased but not determined by the round of asymmetric divisions (8 $\rightarrow$ 16- and 16 $\rightarrow$ 32-cells). Dev Biol 385: 136-148

KUBACZKAC, SENNER C, ARAÚZO-BRAVO MJ, SHARMAN1, KUCKENBERG P1, BECKER A, ZIMMER A, BRÜSTLE O, PEITZ M, HEMBERGER M, SCHORLE $H$ (2014). Derivation and maintenance of murine trophoblast stem cells under defined conditions. Stem Cell Rep 2: 232-242.

KUCKENBERG P, PEITZ M, KUBACZKA C, BECKER A, EGERT A, WARDELMANN E, ZIMMER A, BRÜSTLE O, SCHORLE H (2011). Lineage conversion of murine extraembryonic trophoblast stem cells to pluripotent stem cells. Mol Cell Biol 31: 1748-1756.

KUIJK EW, VAN TOL LT, VAN DE VELDE H, WUBBOLTS R, WELLING M, GEIJSEN $N$, ROELEN BA (2012). The roles of FGF and MAP kinase signaling in the segregation of the epiblast and hypoblast cell lineages in bovine and human embryos. Development 139: 871-882.

KUNATH T, ARNAUD D, UY GD, OKAMOTO I, CHUREAU C, YAMANAKA Y, HEARD E, GARDNER RL, AVNER P, ROSSANT J (2005). Imprinted X-inactivation in extra-embryonic endoderm cell lines from mouse blastocysts. Development 132: 1649-1661.

KUNATH T, SABA-EL-LEIL MK, ALMOUSAILLEAKH M, WRAY J, MELOCHE S, 
SMITHA (2007). FGF stimulation of the Erk1/2 signalling cascade triggers transition of pluripotent embryonic stem cells from self-renewal to lineage commitment. Development 134: 2895-2902.

KUNATH T, YAMANAKA Y, DETMAR J, MACPHEE D, CANIGGIA I, ROSSANT J, JURISICOVA A (2014). Developmental differences in the expression of FGF receptors between human and mouse embryos. Placenta 35: 1079-1088.

KURIMOTO K, KABUTA Y, OHINATA Y, ONO Y, UNO KD, HAMADA RG, UEDA HR, SAITOU M (2006). An improved single-cell cDNA amplification method for efficient high-density oligonucleotide microarray analysis. Nucleic Acids Res 34: e42.

KUROWSKIA, MOLOTKOVA, SORIANO P (2019). FGFR1 regulates trophectoderm development and facilitates blastocyst implantation. Dev Biol 446: 94-101.

LANNER F, LEE KL, SOHL M, HOLMBORN K, YANG H, WILBERTZJ, POELLINGER L, ROSSANT J, FARNEBO F (2010). Heparan sulfation-dependent fibroblast growth factor signaling maintains embryonic stem cells primed for differentiation in a heterogeneous state. Stem Cells 28: 191-200.

LATOS PA, GONCALVES A, OXLEY D, MOHAMMED H, TURRO E, HEMBERGER $M$ (2015). Fgf and Esrrb integrate epigenetic and transcriptional networks that regulate self-renewal of trophoblast stem cells. Nat Commun 6: 7776.

LE BIN GC, MUÑOZ-DESCALZO S, KUROWSKI A, LEITCH H, LOUX, MANSFIELD W, ETIENNE-DUMEAU C, GRABOLE N, MULAS C, NIWA H, HADJANTONAKIS AK, NICHOLS J (2014). Oct4 is required for lineage priming in the developing inner cell mass of the mouse blastocyst. Development 141: 1001-1010.

LEUNDA-CASI A, DE HERTOGH R, PAMPFER S (2001). Control of trophectoderm differentiation by inner cell mass-derived fibroblast growth factor-4 in mouse blastocysts and corrective effect of fgf- 4 on high glucose-induced trophoblast disruption. Mol Rep Dev 60: 38-46.

LEW ED, FURDUI CM, ANDERSON KS, SCHLESSINGER J (2009). The precise sequence of FGF receptor autophosphorylation is kinetically driven and is disrupted by oncogenic mutations. Sci Signal 2: ra6.

LIP, TONG C, MEHRIAN-SHAIR, JIAL, WU N, YAN Y, MAXSON RE, SCHULZE EN, SONG H, HSIEH CL, PERA MF, YING QL (2008) Germline competent embryonic stem cells derived from rat blastocysts. Cell 135: 1299-1310.

LIN HY, KAPLOW J, JAYE M, HAYMAN MJ (1997). Ligand-binding specificity of human fibroblast growth factor receptor-3 IIIc. FEBS Lett. 411(2-3): 389-392.

LIN J, KHAN M, ZAPIEC B, MOMBAERTS P (2016). Efficient derivation of extraembryonic endoderm stem cell lines from mouse postimplantation embryos. $\mathrm{Sci}$ Rep 6: 39457.

LIN J, KHAN M, ZAPIEC B, MOMBAERTS P (2017). PDGFRA is not essential for the derivation and maintenance of mouse extraembryonic endoderm stem cell lines. Stem Cell Rep 9: 1062-1070.

LLOYD AC (2006). Distinct functions for ERKs? J Biol 5: 13.

MACARTHUR CA, LAWSHE A, XU J, SANTOS-OCAMPO S, HEIKINHEIMO M, CHELLAIAH AT, ORNITZ DM (1995). FGF-8 isoforms activate receptor splice forms that are expressed in mesenchymal regions of mouse development. Development 121: 3603-3613.

LU CW, YABUUCHI A, CHEN L, VISWANATHAN S, KIM K, DALEY GQ (2008). RasMAPK signaling promotes trophectoderm formation from embryonic stem cells and mouse embryos. Nat Genet 40:921-926.

MARGARITSM, SONDERMANN H, HALLBE, NAGARB, HOELZA, PIRRUCCELLO M, BAR-SAGID, KURIYANJ (2003). Structural evidence for feedback activation by Ras.GTP of the Ras-specific nucleotide exchange factor SOS. Cell 112: 685-695.

MARTIN GR (1981). Isolation of a pluripotent cell line from early mouse embryos cultured in medium conditioned by teratocarcinoma stem cells. Proc Natl Acad Sci USA 78: 7634-7638.

MASON JM, MORRISON DJ, BASSIT B, DIMRI M, BAND H, LICHT JD, GROSS (2001). Tyrosine Phosphorylation of Sprouty Proteins Regulates Their Ability to Inhibit Growth Factor Signaling:ADual Feedback Loop. Mol Biol Cell15:2176-2188.

MATALLANAS D, BIRTWISTLE M, ROMANO D, ZEBISCH A, RAUCH J, VON KRIEGSHEIM A, KOLCH W (2011). Raf family kinases: old dogs have learned new tricks. Genes Cancer 2: 232-260.

MAYSHAR Y, ROM E, CHUMAKOV I, KRONMAN A, YAYON A, BENVENISTY N (2008). Fibroblast growth factor 4 and its novel splice isoform have opposing effects on the maintenance of human embryonic stem cell self-renewal. Stem Cells 26: 767-774.

MEILHAC SM, ADAMS RJ, MORRIS SA, DANCKAERTA, LE GARREC JF, ZERNICKA-GOETZ M (2009). Active cell movements coupled to positional induction are involved in lineage segregation in the mouse blastocyst. Dev Biol 331: 210-221.

MESSERSCHMIDT DM, KEMLER R (2010). Nanog is required for primitive endoderm formation through a non-cell autonomous mechanism. Dev Biol 344: 129-137.

MIKI T, BOTTARO DP, FLEMING TP, SMITH CL, BURGESS WH, CHAN AM, AARONSON SA (1992). Determination of ligand-binding specificity by alternative splicing: two distinct growth factor receptors encoded by a single gene. Proc Nat Acad Sci USA 89: 246-250.

MILNE DM, CAMPBELL DG, CAUDWELL FB, MEEK DW (1994). Phosphorylation of the tumor suppressor protein $\mathrm{p} 53$ by mitogen-activated protein kinases. $\mathrm{J}$ Biol Chem 269: 9253-9260.

MIN H, DANILENKO DM, SCULLY SA, BOLON B, RING BD, TARPLEY JE, DEROSE M, SIMONET WS (1998). Fgf-10 is required for both limb and lung development and exhibits striking functional similarity to Drosophila branchless. Genes Dev 12: 3156-3161.

MISTRI TK, ARINDRARTO W, NG WP, WANG C, LIM LH, SUN L, CHAMBERS I, WOHLAND T, ROBSON P (2018). Dynamic changes in Sox2 spatio-temporal expression promote the second cell fate decision through Fgf4/Fgfr2 signaling in preimplantation mouse embryos. Bioch J 475: 1075-1089.

MOHAMMADI M, DIKIC I, SOROKIN A, BURGESS WH, JAYE M, SCHLESSINGER $\mathrm{J}$ (1996a). Identification of six novel autophosphorylation sites on fibroblast growth factor receptor 1 and elucidation of their importance in receptor activation and signal transduction. $\mathrm{Mol}$ Cell Biol 16: 977-989.

MOHAMMADI M, SCHLESSINGER J, HUBBARD SR (1996b). Structure of the FGF receptor tyrosine kinase domain reveals a novel autoinhibitory mechanism. Cell 86: 577-587

MOLOTKOV A, MAZOT P, BREWER JR, CINALLI RM, SORIANO P (2017). Distinct requirements for FGFR1 and FGFR2 in primitive endoderm development and exit from pluripotency. Dev Cell 41: 511-526.

MOLOTKOV A, SORIANO P (2018). Distinct mechanisms for PDGF and FGF signaling in primitive endoderm development. Dev Biol 442: 155-161.

MORADI M, RIASI A, OSTADHOSSEINI S, HOSSEINI M, NASR-ESFAHANI MH (2015). Expression profile of FGF receptors in preimplantation ovine embryos and the effect of FGF2 and PD173074. Growth factors 33(5-6): 393-400.

MORGANI SM, SAIZ N, GARG V, RAINA D, SIMON CS, KANG M, ARIAS AM, NICHOLS J, SCHRÖTER C, HADJANTONAKIS AK (2018). A Sprouty4 reporter to monitor FGF/ERK signaling activity in ESCs and mice. Dev Biol 441: 104-126.

MORRIS SA, GRAHAM SJ, JEDRUSIK A, ZERNICKA-GOETZ M (2013). The differential response to Fgf signalling in cells internalized at different times influences lineage segregation in preimplantation mouse embryos. Open Biol 3: 130104

MORRIS SA, TEO RT, LI H, ROBSON P, GLOVERDM, ZERNICKA-GOETZM (2010). Origin and formation of the first two distinct cell types of the inner cell mass in the mouse embryo. Proc Natl Acad Sci USA 107: 6364-6369.

MORTON S, DAVIS RJ, MCLAREN A, COHEN P (2003). A reinvestigation of the multisite phosphorylation of the transcription factor c-Jun. EMBOJ22:3876-3886.

MURPHY LO, SMITH S, CHEN RH, FINGAR DC, BLENIS J (2002). Molecular interpretation of ERK signal duration by immediate early gene products. Nat Cell Biol 4: 556-564.

NATALE DR, HEMBERGER M, HUGHES M, CROSS JC (2009). Activin promotes differentiation of cultured mouse trophoblast stem cells towards a labyrinth cell fate. Dev Biol 335: 120-131.

NEKRASOVA T, SHIVE C, GAO Y, KAWAMURA K, GUARDIA R, LANDRETH G FORSTHUBER TG (2005). ERK1-deficient mice show normal T cell effector function and are highly susceptible to experimental autoimmune encephalomyelitis. J Immunol 175: 2374-2380.

NIAKAN KK, EGGAN K (2013). Analysis of human embryos from zygote to blastocys reveals distinct gene expression patterns relative to the mouse. Dev Bio/375:54-64

NICHOLS J, ZEVNIK B, ANASTASSIADIS K, NIWA H, KLEWE-NEBENIUS D, CHAMBERS I, SCHÖLER H, SMITH A (1998). Formation of pluripotent stem cells in the mammalian embryo depends on the POU transcription factor Oct4. Cell 95: 379-391.

NICHOLS J, JONES K, PHILLIPS JM, NEWLAND SA, ROODE M, MANSFIELD W, SMITH A, COOKE A (2009a). Validated germline-competent embryonic stem cel lines from nonobese diabetic mice. Nat Med 15: 814-818

NICHOLS J, SILVA J, ROODE M, SMITH A (2009b). Suppression of Erk signalling promotes ground state pluripotency in the mouse embryo. Development 136: 3215-3222. 
NICHOLS J, SMITH A (2009) Naive and primed pluripotent states. Cell Stem Cell 4: 487-492.

NISHIOKA N, INOUE K, ADACHI K, KIYONARI H, OTA M, RALSTON A, YABUTA N, HIRAHARA S, STEPHENSON RO, OGONUKI N, et al., (2009). The Hippo signaling pathway components Lats and Yap pattern Tead4 activity to distinguish mouse trophectoderm from inner cell mass. Dev Cell 16: 398-410.

NIWA H, BURDON T, CHAMBERS I, SMITH A (1998). Self-renewal of pluripotent embryonic stem cells is mediated via activation of STAT3. Genes Dev 12: 2048-2060.

OGAWA H, TAKYU R, MORIMOTO H, TOEI S, SAKON H, GOTO S, MORIYA S, KONO T (2016). Cell proliferation potency is independent of FGF4 signaling in trophoblast stem cells derived from androgenetic embryos. JReprod Dev62:51-58.

OHNISHI Y, HUBER W, TSUMURA A, KANG M, XENOPOULOS P, KURIMOTO K, OLEŚ AK, ARAÚZO-BRAVO MJ, SAITOU M, HADJANTONAKIS AK, HIIRAGI T (2014). Cell-to-cell expression variability followed by signal reinforcement progressively segregates early mouse lineages. Nat Cell Biol 16: 27-37.

OKAE H, TOH H, SATO T, HIURA H, TAKAHASHI S, SHIRANE K, KABAYAMA Y, SUYAMA M, SASAKI H, ARIMA T (2018). Derivation of Human Trophoblast Stem Cells. Cell Stem Cell 22: 50-63.

OLSEN SK, IBRAHIMI OA, RAUCCI A, ZHANG F, ELISEENKOVA AV, YAYON A, BASILICO C, LINHARDTRJ, SCHLESSINGERJ, MOHAMMADIM (2004). Insights into the molecular basis for fibroblast growth factor receptor autoinhibition and ligand-binding promiscuity. Proc Natl Acad Sci USA 101: 935-940.

ONG SH, GUY GR, HADARI YR, LAKS S, GOTOH N, SCHLESSINGER J, LAX I (2000). FRS2 proteins recruit intracellular signaling pathways by binding to diverse targets on fibroblast growth factor and nerve growth factor receptors. Mol Cell Biol 20: 979-989.

ORNITZDM, ITOHN (2001). Fibroblast growth factors. Genome Biol2: REVIEWS3005.

ORNITZ DM, ITOH N (2015). The Fibroblast Growth Factor signaling pathway. Wiley Interdiscip Rev Dev Biol 4: 215-266.

ORNITZ DM, XU J, COLVIN JS, MCEWEN DG, MACARTHUR CA, COULIER F, GAO G, GOLDFARB M (1996). Receptor specificity of the fibroblast growth factor family. J Biol Chem 271: 15292-15297.

ORR-URTREGER A, BEDFORD M. T, BURAKOVA T, ARMAN E, ZIMMER Y, YAYON A, GIVOL D, LONAI P (1993). Developmental localization of the splicing alternatives of fibroblast growth factor receptor-2 (FGFR2). Dev Biol 158: 475-486.

OZAWA M, YANG QE, EALY AD (2013). The expression of fibroblast growth factor receptors during early bovine conceptus development and pharmacological analysis of their actions on trophoblast growth in vitro. Reproduction 145: 191 -201.

PARTANEN J, MAKELATP, EEROLA E, KORHONEN J, HIRVONEN H, CLAESSONWELSH L, ALITALO K (1991). FGFR-4, a novel acidic Fibroblast Growth Factor receptor with a distinct expression pattern. EMBO J 10: 1347-1354.

PILISZEKA, MADEJAZE, PLUSA B (2017). Suppression of ERK signalling abolishes primitive endoderm formation but does not promote pluripotency in rabbit embryo. Development 144: 3719-3730.

PLOTNIKOVAN, HUBBARD SR, SCHLESSINGERJ, MOHAMMADI M (2000). Crystal structures of two FGF-FGFR complexes reveal the determinants of ligand-receptor specificity. Cell 101: 413-424.

PLOTNIKOV AN, SCHLESSINGER J, HUBBARD SR, MOHAMMADI M (1999). Structural basis for FGF receptor dimerization and activation. Cell 98: 641-650.

PLUSAB, PILISZEKA, FRANKENBERG S, ARTUS J, HADJANTONAKIS AK (2008). Distinct sequential cell behaviours direct primitive endoderm formation in the mouse blastocyst. Development 135: 3081-3091.

POUEYMIROU WT, AUERBACH W, FRENDEWEY D, HICKEY JF, ESCARAVAGE JM, ESAU L, DORÉ AT, STEVENS S, ADAMS NC, DOMINGUEZ MG, GALE NW, YANCOPOULOS GD, DECHIARA TM, VALENZUELA DM (2007). F0 generation mice fully derived from gene-targeted embryonic stem cells allowing immediate phenotypic analyses. Nat Biotechnol 25: 91-99.

POWERS CJ, MCLESKEY SW, WELLSTEIN A (2000). Fibroblast growth factors, their receptors and signaling. Endocr Relat Cancer 3: 165-197.

QIAN X, ESTEBAN L, VASS WC, UPADHYAYA C, PAPAGEORGE AG, YIENGER K, WARD JM, LOWY DR, SANTOS E (2000). The Sos1 and Sos2 Ras-specific exchange factors: differences in placental expression and signaling properties. EMBO J 19: 642-654

RAJALINGAM K, SCHRECK R, RAPP UR, ALBERT S (2007). Ras oncogenes and their downstream targets. Biochem Biophys Acta 1773: 1177-1195.
REINHOLDT LG, HOWELL GR, CZECHANSKI AM, MACALINAO DG, MACNICOLL KKH, LIN CS, DONAHUE LR, JOHN SWM (2012). Generating embryonic stem cells from the inbred mouse strain DBA/2J, a model of glaucoma and other complex diseases. PLoS One 7: e50081.

REN Y, LI Z, RONG Z, CHENG L, LI Y, WANG Z, CHANG Z (2007). Tyrosine 330 in hSef is critical for the localization and the inhibitory effect on FGF signaling. Biochem Biophys Res Commun 354: 741-746.

RODRIGUEZ A, ALLEGRUCCI C, ALBERIO R (2012). Modulation of pluripotency in the porcine embryo and iPS cells. PLOS ONE 7: e49079.

ROODE M, BLAIR K, SNELL P, ELDER K, MARCHANT S, SMITH A, NICHOLS J (2012). Human hypoblast formation is not dependent on FGF signalling. Dev Biol 361: 358-363.

ROSKOSKI R JR (2012). ERK1/2 MAP kinases: structure, function, and regulation. Pharmacol Res 66: 105-143.

SABA-EL-LEIL MK, VELLA FD, VERNAY B, VOISIN L, CHEN L, LABRECQUE N, ANG SL, MELOCHE S (2003). An essential function of the mitogen-activated protein kinase Erk2 in mouse trophoblast development. EMBO Rep 4: 964-968.

SAINI D, YAMANAKA Y (2018). Cell polarity-dependent regulation of cell allocation and the first lineage specification in the preimplantation mouse embryo. Curr Top Dev Biol 128: 11-35.

SAIZ N, GRABAREK JB, SABHERWAL N, PAPALOPULU N, PLUSAB (2013). Atypical protein kinase $C$ couples cell sorting with primitive endoderm maturation in the mouse blastocyst. Development 140: 4311-4322.

SAIZ N, WILLIAMS KM, SESHAN VE, HADJANTONAKIS AK (2016). Asynchronous fate decisions by single cells collectively ensure consistent lineage composition in the mouse blastocyst. Nat Commun 7: 13463.

SARABIPOUR S, HRISTOVA K (2016). Mechanism of FGF receptor dimerization and activation. Nat Commun 7: 10262.

SASAKI A, TAKETOMI T, WAKIOKA T, KATO R, YOSHIMURA A (2001). Identification of a dominant negative mutant of Sprouty that potentiates fibroblast growth factor but not epidermal growth factor-induced ERK activation. J Biol Chem 276: 36804-36808.

SCHLESSINGER J, PLOTNIKOV AN, IBRAHIMI OA, ELISEENKOVA AV, YEH BK, YAYON A, LINHARDT RJ, MOHAMMADI M (2000). Crystal structure of a ternary FGF-FGFR-heparin complex reveals a dual role for heparin in FGFR binding and dimerization. Mol Cell 6: 743-750.

SCHOORLEMMERJ, KRUIJERW (1991). Octamer-dependent regulation of the KFGF gene in embryonal carcinoma and embryonic stem cells. Mech Dev36(1-2):75-86.

SCHRODE N, SAIZ N, DI TALIA S, HADJANTONAKIS AK (2014). GATA6 levels modulate primitive endoderm cell fate choice and timing in the mouse blastocyst. Dev Cell 29: 454-467.

SCHRÖTER C, RUÉ P, MACKENZIE JP, MARTINEZ ARIAS A (2015). fgf/mapk signaling sets the switching threshold of a bistable circuit controlling cell fate decisions in embryonic stem cells. Development 142: 4205-4216.

SILVA J, NICHOLS J, THEUNISSEN TW, GUO G, VAN OOSTEN AL, BARRANDON O, WRAY J, YAMANAKAS, CHAMBERS I, SMITHA (2009). Nanog is the gateway to the pluripotent ground state. Cell 138: 722-737.

SIMON JA, SCHREIBER SL (1995). Grb2 SH3 binding to peptides from Sos: evaluation of a general model for SH3-ligand interactions. Chem Biol 2: 53-60.

SINGH AM, HAMAZAKI T, HANKOWSKI KE, TERADA N (2007). A heterogeneous expression pattern for Nanog in embryonic stem cells. Stem Cells 25: 2534-2542.

SONG Y, LEE S, JHO EH (2018). Enhancement of neuronal differentiation by using small molecules modulating Nodal/Smad, Wnt/ $\beta$-catenin, and FGF signaling. Biochem Biophys Res Commun 503: 352-358.

SPRUCE T, PERNAUTE B, DI-GREGORIO A, COBB BS, MERKENSCHLAGER M, MANZANARES M, RODRIGUEZ TA (2010). An early developmental role for miRNAs in the maintenance of extraembryonic stem cells in the mouse embryo. Dev Cell 19: 207-219.

STAVRIDIS MP, LUNN JS, COLLINS BJ, STOREY KG (2007). A discrete period of FGF-induced Erk1/2 signalling is required for vertebrate neural specification. Development 134: 2889-2894.

TAN T, TANG X, ZHANG J, NIU Y, CHEN H, LI B, WEI Q, JI W (2011). Generation of trophoblast stem cells from rabbit embryonic stem cells with BMP4. PLOS One 6: e17124.

TANAKA S, KUNATH T, HADJANTONAKIS AK, NAGY A, ROSSANT J (1998). Pro- 
motion of trophoblast stem cell proliferation by FGF4. Science 282: 2072-2075.

TESAR PJ, CHENOWETH JG, BROOK FA, DAVIES TJ, EVANS EP, MACK DL, GARDNER RL, MCKAY RD (2007). New cell lines from mouse epiblast share defining features with human embryonic stem cells. Nature 12;448: 196-199.

THOMSON JA, ITSKOVITZ-ELDOR J, SHAPIRO SS, WAKNITZ MA, SWIERGIEL JJ, MARSHALL VS, JONES JM (1998). Embryonic stem cell lines derived from human blastocysts. Science 282: 1145-1147.

THOMSON JA, KALISHMAN J, GOLOS TG, DURNING M, HARRIS CP, BECKER RA, HEARN JP (1995). Isolation of a primate embryonic stem cell line. Proc Natl Acad Sci USA 92: 7844-7848.

THOMSON JA, KALISHMAN J, GOLOS TG, DURNING M, HARRIS CP, HEARN JP (1996). Pluripotent cell lines derived from common marmoset (Callithrix jacchus) blastocysts. Biol Reprod 55: 254-259.

TOYOOKA Y, SHIMOSATO D, MURAKAMI K, TAKAHASHI K, NIWA H (2008). Identification and characterization of subpopulations in undifferentiated ES cell culture. Development 135: 909-918.

UY GD, DOWNS KM, GARDNER RL (2002). Inhibition of trophoblast stem cell potential in chorionic ectoderm coincides with occlusion of the ectoplacental cavity in the mouse. Development 129: 3913-3924.

VANDER JEUGHTM, O'LEARYT, GHIMIRES, LIERMANS, DUGGALG, VERSIEREN $K$, DEFORCE D, CHUVA DE SOUSA LOPES S, HEINDRYCKX B, DE SUTTER $P$ (2013). The combination of inhibitors of FGF/MEK/Erk and GSK3 $\beta$ signaling increases the number of OCT3/4- and NANOG-positive cells in the human inner cell mass, but does not improve stem cell derivation. Stem Cells Dev22: 296-306.

VANDEVOORT CA, THIRKILL TL, DOUGLAS GC (2007). Blastocyst-derived trophoblast stem cells from the rhesus monkey. Stem Cells Dev 16: 779-788.

VOGEL S, KUBIN T, VON DER AHE D, DEINDL E, SCHAPER W, ZIMMERMANN R (2006). MEK hyperphosphorylation coincides with cell cycle shut down of cultured smooth muscle cells. J Cell Physiol 206: 25-34.

WERNER S, DUAN DS, DE VRIES C, PETERS KG, JOHNSON DE, WILLIAMS LT (1992). Differential splicing in the extracellular region of Fibroblast Growth Factor receptor 1 generates receptor variants with different ligand-binding specificities. $\mathrm{Mol}$ Cell Biol 12: 82-88.

WICKLOW E, BLIJ S, FRUM T, HIRATE Y, LANG RA, SASAKI H, RALSTONA (2014). HIPPO pathway members restrict SOX2 to the inner cell mass where it promotes ICM fates in the mouse blastocyst. Plos Genet 10: e1004618.

WIGGER M, KISIELEWSKA K, FILIMONOW K, PLUSA B, MALESZEWSKI M, SUWIŃSKA A (2017). Plasticity of the inner cell mass in mouse blastocyst is restricted by the activity of FGF/MAPK pathway. Sci Rep 7: 15136.

WILDER PJ, KELLY D, BRIGMAN K, PETERSON CL, NOWLING T, GAO QS, MCCOMB RD, CAPECCHI MR, RIZZINO A (1997). Inactivation of the FGF-4 gene in embryonic stem cells alters the growth and/or the survival of their early differentiated progeny. Dev Biol 192: 614-629.

WONG A, LAMOTHE B, LEE A, SCHLESSINGER J, LAX I (2002). FRS2 alpha at- tenuates FGF receptor signaling by Grb2-mediated recruitment of the ubiquitin ligase Cbl. Proc Natl Acad Sci USA: 14;99: 6684-6689.

XENOPOULOSP, KANG M, PULIAFITOA, DITALIAS, HADJANTONAKISAK (2015). Heterogeneities in Nanog Expression Drive Stable Commitment to Pluripotency in the Mouse Blastocyst. Cell Rep 10: 1508-1520.

XU X, WEINSTEIN M, LI C, NASKI M, COHEN RI, ORNITZ DM, LEDER P, DENG C. (1998). Fibroblast growth factor receptor 2 (FGFR2)- mediated reciprocal regulation loop between FGF8 and FGF10 is essential for limb induction. Development 125: 753-765.

XU B, WILSBACHER JL, COLLISSON T, COBB MH (1999). The N-terminal ERKbinding site of MEK1 is required for efficient feedback phosphorylation by ERK2 in vitro and ERK activation in vivo. J Biol Chem 274: 34029-34035.

YAMANAKA Y, LANNER F, ROSSANT J (2010). FGF signal-dependent segregation of primitive endoderm and epiblast in the mouse blastocyst. Development, 137 715-724.

YAN G, FUKABORI Y, MCBRIDE G, NIKOLAROPOLOUS S, MCKEEHAN WL (1993). Exon switching and activation of stromal and embryonic fibroblast growth factor (FGF)-FGF receptor genes in prostate epithelial cells accompany stromal independence and malignancy. Mol Cell Biol 13: 4513-4522.

YAN KS, KUTI M, YAN S, MUJTABA S, FAROOQ A, GOLDFARB MP, ZHOU MM (2002). FRS2 PTB domain conformation regulates interactions with divergent neurotrophic receptors. J Biol Chem 277:17088-17094.

YANG Y, ZHANG D, YU Y, ZHANG RJ, HU XL, HUANG HF, LU YC (2015). Binding of FGF2 to FGFR2 in an autocrine mode in trophectoderm cells is indispensable for mouse blastocyst formation through PKC-p38 pathway. Cell cycle 14: 3318-3330

YAO Y, LI W, WU J, GERMANN UA, SU MS, KUIDA K, BOUCHER DM (2003). EXtracellular signal-regulated kinase 2 is necessary for mesoderm differentiation. Proc Natl Acad Sci USA 100: 12759-12764.

YEH BK, IGARASHI M, ELISEENKOVA AV, PLOTNIKOV AN, SHER I, RON D, AARON-SON SA, MOHAMMADI M (2003). Structural basis by which alternative splicing confers specificity in fibroblast growth factor receptors. Proc Natl Acad Sci USA 100: 2266-2271.

YING QL, NICHOLS J, CHAMBERS I, SMITH A (2003). BMP induction of Id proteins suppresses differentiation and sustains embryonic stem cell self-renewal in collaboration with STAT3. Cell 115: 281-292.

YING QL, WRAY J, NICHOLS J, BATLLE-MORERA L, DOBLE B, WOODGETT J, COHEN P, SMITHA (2008). The ground state of embryonic stem cell self-renewal. Nature 453: 519-523.

YU K, XU J, LIU Z, SOSIC D, SHAO J, OLSON EN, TOWLER DA, ORNITZ DM (2003). Conditional inactivation of FGF receptor 2 reveals an essential role for FGF signaling in the regulation of osteoblast function and bone growth. Development 130: 3063-3074

YUAN H, CORBI N, BASILICO C, DAILEY L (1995). Developmental-specific activity of the FGF-4 enhancer requires the synergistic action of Sox2 and Oct-3. Genes Dev 9: 2635-2645 


\section{Further Related Reading, published previously in the Int. J. Dev. Biol.}

Cell signaling in trophoblast-uterine communication

Rani Fritz, Chandni Jain and D. Randall Armant

Int. J. Dev. Biol. (2014) 58: 261-271

https://doi.org/10.1387/ijdb.140011da

Signaling pathways dictating pluripotency in embryonic stem cells

Debasree Dutta

Int. J. Dev. Biol. (2013) 57: 667-675

https://doi.org/10.1387/ijdb.130064dd

Signaling pathways during maintenance and definitive endoderm differentiation of embryonic stem cells

Lina Sui, Luc Bouwens and Josué K. Mfopou

Int. J. Dev. Biol. (2013) 57: 1-12

Pluripotency of bank vole embryonic cells depends on FGF2 and activin A signaling pathways

Aneta Suwinska, Andrzej K. Tarkowski and Maria A. Ciemerych

Int. J. Dev. Biol. (2010) 54: 113-124

https://doi.org/10.1387/ijdb.082704as

Role of TGF beta and myofibroblasts in supporting the propagation of human embryonic stem cells in vitro

Neeraj Kumar, Prasad Pethe and Deepa Bhartiya

Int. J. Dev. Biol. (2010) 54: 1329-1336

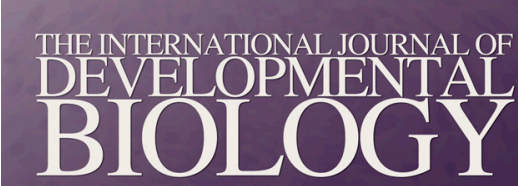

Volume 60 Nos. $10 / 11 / 12$

Special Issue

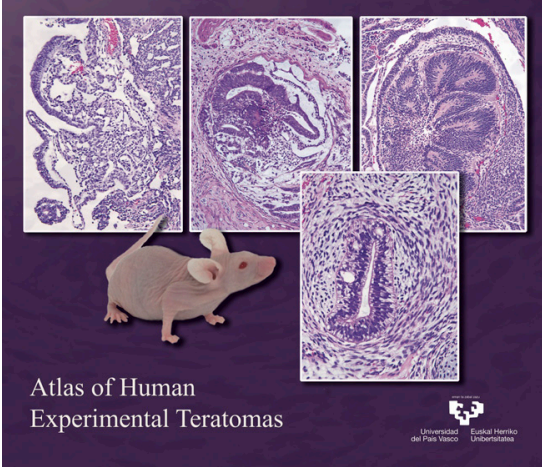

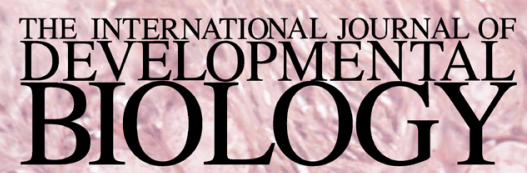

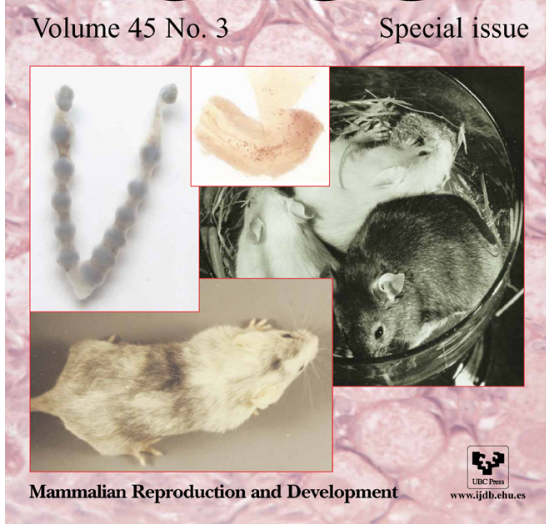

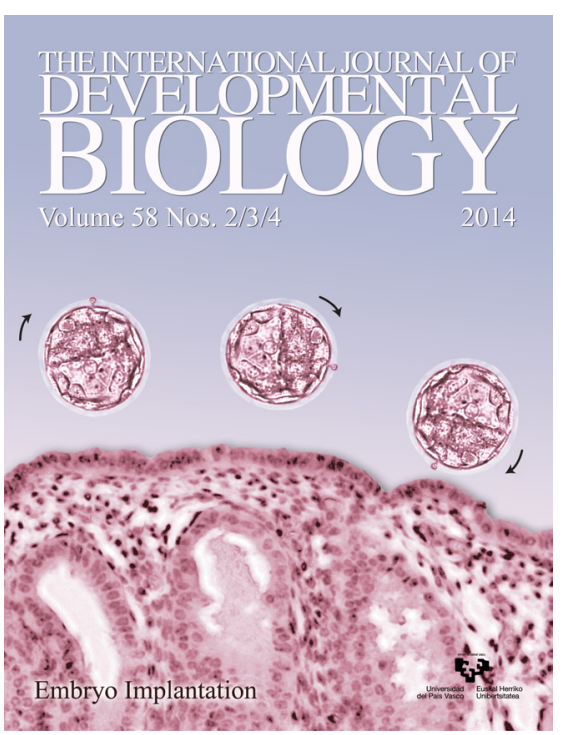

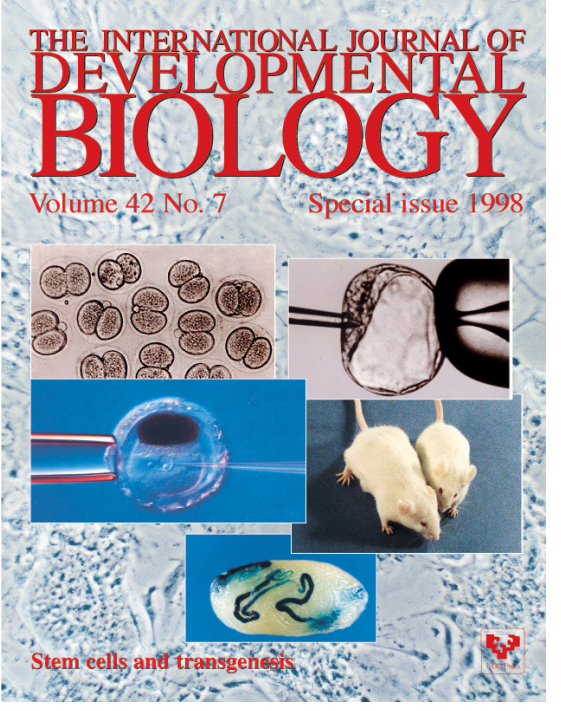

